\title{
Development of a parametric matrix based on GSCM literature
}

\author{
M. B. Nidhi ${ }^{a^{*}}$ and V. Madhusudanan Pillai ${ }^{b}$
}

${ }^{a}$ Research Scholar, Mechanical Engineering Department, National Institute of Technology Calicut, India ${ }^{b}$ Associate Professor, Mechanical Engineering Department, National Institute of Technology Calicut, India

C H R O N I C L E

Article history:

Received December 5, 2015

Received in revised format

February 162016

Accepted April 262016

Available online

April 282016

Keywords:

Green supply chain

Parametric matrix

Corporate social responsibility

Sustainable chain

Social responsibility index

\begin{abstract}
A B S T R A C T
Today Green Supply Chain Management (GSCM) still remains as an attempt alone. For more than a decade, supply chain evolution to be a low carbon chain in an energy and resource constrained world has been posing greater challenges. Though environmental policies remain without much variation towards green operations in an industry, the implantation strategies and stages vary. There have been a number of studies by researchers and a lot of endeavors by organizations to build a green supply chain, mainly because of pressure from the professional bodies like EPA, WEEE, OECD, and Clean Air Act to reduce emissions with growing concerns over climate change issues, global warming, and requirements from policy makers, end users, stake holders and others. But, at the implementation level there lacked a proper framework on GSCM which suggests guidelines for proper planning and coordination, and the practices to be adopted. This indicates the need for a complete strategic approach on the part of decision makers across the supply chain to have sustainability as a corporate social responsibility. The research gap exists in a holistic perception with regard to a product when supply chain stages are mapped for sustainability due to diverse environmental issues. Also, to build a holistic approach, we must know how the stages and levels interact. Thus, in this work, a Parametric Matrix demarking various level and stages of a supply chain related to a product, in general, is developed from various literatures till date. Such a metric will be useful for the industries to identify the bottleneck areas in their supply chain towards sustainability. Hence, the desired and relevant level of factors to be considered at each stage to become green can easily be decided.
\end{abstract}

\section{Introduction}

Ever since the discoveries on new gadgets for lifestyle improvement started, there has been a tremendous burden on the environment of earth. As a result there has been a greater emphasize on the environmental friendly disposal of post consumed goods and bi-product. This large volume of manufacturing, consumption and disposal has led to energy requirements in 'exa-joules'. This steered the industry environment management system to include responsibility for ensuring environmental excellence in product development, process design, operations, logistics, marketing, regulatory compliance, and waste management. In the recent years Green Supply Chain Management (GSCM) * Corresponding author. 
has been gaining importance due to i) diminishing raw materials, ii) deterioration of environment, iii) overflowing of waste in lands, and iv) increasing levels of pollution. This indicates the need for new guidelines based on convergence of economy and environment, ecology as performance indicator and environment commitment, in the long run. Evolution of Supply Chain Management (SCM) and its implementation has been at stake in an energy constrained low carbon world, irrespective of technological advancements anticipated for better productivity and flexibility to the chain. The word green thus settles here with one of the first steps as tracing the carbon emissions across the chain in terms of carbon foot print. In future, the green claim may need to account for other emissions, noise pollution, landfills, etc.

Apart from Economic Sustainability, a firm must focus to attain environmental sustainability through proper integration of internal and external competence, and recombination of resources for effective use. Today climate change is a serious concern with every nation sharing the responsibility to be green and clean. As a result, bodies/regulations like EPA, WEEE, OECD, Clean Air Act, etc. have emerged to insist on the need for environmental healthy material choices for products as well as on the usage till the end of its life cycle. To ensure end of life usage, the options like recycling and remanufacturing have emerged which lead to integration of reverse logistics to SCM (closed loop SCM). During 1990s the management of SC gained importance which lead to the evolution of value chain, then to closed loop SCM further to sustainable or GSCM aiming to integrate all the factors associated with a product. The forward chain of GSCM accounts for the sourcing of raw material, the process it undergoes to develop as a product through various stages of manufacturing, then its packing, transportation from plant to distributors to the end customer. The backward chain of GSCM involves reverse logistics and some returns of reusable components to the respective stages of SC from the collection centres. Examples cover the packing material returns, post consumed electronic goods, post consumed PET bottles, etc. Dell saved over 20 million by recovering packing material, and Pepsi-Cola saved 44 million by using reusable containers; reverse logistics used in organizations such as BMW and General Motors (automobile industries), Hewlett Packard, Storage Tek and TRW are Samples for initiations towards being green found in Dube and Gawande (2012). Thus, the interactions in a chain, even for a simple product in real-life, are so complex that demand new models, heuristics, simulations and various integrations like information, transportation which are to be tried out to enhance the value in SC.

This paper uncovers a comprehensive Parametric Matrix on major factors of GSCM. The matrix tries to link the triple point bottom line of sustainability of any business to corporate social responsibility (CSR) and GSCM. The aspects covered in this matrix thrust on the activities of the real life players in SCM such as supply chain managers, procurement professionals, logistics managers, policy makers, manufacturers, logistics service providers, strategy departments, business development managers, decision makers in all industries and hierarchies, and consumers to operations team in dismantling centres. Though environmental policies can be adopted without many variations from previous research works, the implementation of GSCM does vary in strategies to be adapted due to differences in one industry to another, country to country and product to product. This led to consider Green as onerous (Hanna, 1996; Clemens et al., 2008; Handfield et al., 2002). Some of the barriers to adopt green embrace (i) lack of clarity for the green initiatives, (ii) lack of goal setting by leaders, (iii) attitude barrier because it is perceived to incur high cost and reduce SCM efficiency, (iv) fear for coordination / cooperation among the players of SC, (v) lack of control on the supplier methods, (vi) top management strategy misaligned with green initiatives, etc. But being green at firm level is a necessity (Anderson, 2000; Bansal, 2003; de Ruyter et al., 2009; Drumwright, 1994; Varadarajan, 1992). Thus, we find there are research arguments that exist supporting and contradicting in the context of being Green Supply Chain (GSC). In the light of negative arguments for being green we can find lots of studies discussing about profitability from being sustainable rather termed as green gold. The diversity in thrust area of SCM has resulted in defining the green supply chain and sustainable SCM separately. A comprehensive review covered by Ahi and Searcy, (2013) and Hassini et al. (2012a) indicates drastic differences in approach to GSCM and Sustainable SCM (SSCM), which shows difficulty and 
confusion. This may lead to delay in adopting sustainability and its implementation in operations. In the present work we are making an attempt to bridge this gap of GSCM and SSCM by introducing a parameter matrix with micro level factors. In order to aid practitioners and researchers of SCM and to implement sustainability in operations, a parametric matrix has been developed in this paper.

This paper is organised with literature review in Section 2 which covers the general/broad dimensions of GSCM among the vast research works. Section 3 depicts green supply chain Parametric Matrix formation and the literature supporting the development of this matrix. Section 4 deals with numerical methods applied to sustainable SCM mainly covering empirical works and models based on LCA and Cost/profit. Section 5 explains the need for including sustainability as corporate social responsibility and Section 6 gives directions for new research. Finally, the conclusion is given in Section 7. To the best knowledge of authors this is one of the first attempts to combine various stages and levels associated in a supply chain incorporating strategic, tactical and operational decisions for implementing green value chain at micro level for any product.

\section{Literature Review}

\subsection{General Introduction}

Being a broad area, comprehending the various dimensions of GSCM was a major difficulty faced by many researchers over the decade. A recent review was on an overview of GSCM in developed and developing countries emphasising the lack of studies in GSCM from developing nations (Jusoh \& Arif, 2012). From earlier studies some major barriers to environmental adaptation are (i) lack of top management involvement to solve environmental issues connected with the industry, re-porting sustainable development and individual involvement (Ramus, 2001; Olivier Boiral \& Yang Chen, 2013), (ii) lack of inclusion regarding environmental concerns in corporate strategy and complexity of environmental orientation due to multidimensional nature (Banerjee, 1998; Subhabrata, 2003), (iii) manufacturing planning and design without eco-friendliness (Hanna, 1996; Angell,1999), and (iv) lack of motivation and skill for the workers on environmental solutions (Azzone 1998; Handfield et al., 2002), especially with purchase professionals being unaware and not knowing how to tackle green purchasing by Wilkerson (2005). Today, there exists, at many corporates a lack of awareness and violation of rules at workers level as real hurdles to enforce the sustainability in spite of reminders. At this juncture, a major breakthrough that should be considered is the introduction of Dominant Social Paradigm (DSP) into research studies (Dunlap,1978; Pirages \& Ehrlich, 1974). A recent definition of DSP by (Kilbourne \& Beckmann, 1998.a) is, "the shared beliefs and values that makeup a cultures worldview and that functions as ideology". The work related to the three stages of green business is given as first one being the green marketing for green products (Baker \& Sinkula, 2005; Carter \& Rogers, 2008; Hall \& HarrieVredenburg, 2005; Kilbourne \& Beckmann, 1998a), second being the green legislative initiatives relating to reduce resource use and wastage, and recycling, third being general sustainability. The second and third are not having clear agenda and are got sparser. This gap indicates a need from Macro-orientation to micro-operational level to keep track the green attempts and follow-up for continuous preservation for sustainability. The internal reorientation of resources and activities are studied at firm level for environmental sensitivity by Buysee (2003) who classified firms typologies in proactive modes (leadership towards being green incorporating pollution prevention) and reactive modes. In the present work, the primary focus is to incorporate green practices in both modes on SCM stages like procurement, design and manufacture, logistics for distribution, reverse logistics and disposal. The concept of green labelling was used to indicate product manufactured in environmental conscious adoptions than the conventional methods. The green labelling in Sweden has found place in academic research in the context of green consumerism. The voluntary instruments for eco-standards introduced on the market with regard to environmental concern among consumers consist of eco-labels, stewardship certificates, voluntary negotiated agreements, green mutual funds, environmental management systems, environmental declarations, and codes of con-duct, reporting standards, and even certain trademarks with an eco-friendly profile are seen in M Bostrm (2008). Some 
works depict another direction of environment responsibility by linking concurrent engineering through SC collaborations to solve conflicts in decision making and thereby leading to continuous improvement to reduce the adverse impact on nature (Zussman \& Kriwet,1995; Junquera \& del Bro, 2012). The Dynamic Capability Model (DCM) which meets the changing needs of business (Martin, 2000; Winter, 2003 ) and the sustainable needs by Russo (2007) is a new turning point in GSCM. Innovation to be green is yet another approach tried by many researchers. The innovation process here means the use of new technical and administrative knowledge, and the adoption of green practices (Sadorsky \& Henriques, 2007; Rothenberg \& Zyglidopoulos, 2007).

In a review by Gupta et al., Ilgin \& Gupta (2010) one could find a mention on Environmentally Conscious Manufacturing (ECM), Design For Environment (DFE), Design For X (DFX) where X stands for life cycle analysis and material Selection, Design For Recycling (DFR), Grey Relational Analysis (GRA) applied in Quality Function Deployment (QFD), Life Cycle Costing (LCC), Life Cycle Engineering (LCE), Analytical Hierarchy Process (AHP), Analytic Network Process (ANP), Activity Based Costing (ABC), Third Party De-manufacturing (TPD), Symbiotic Logistics Concept (SLC), Virtual Reverse Logistics Network (VRLN) Integrated Disassembly and Recycling Score (IDRS), Fuzzy Logic (FL), fuzzy connected graph, fuzzy multi-attribute and also a number of tools for DFX. The above paper mainly focuses on environmental issues related to product manufacturing and product recoveries from tactical and operational perceptive. Incorporating Environmental Management Systems as a method to achieve waste reduction, increase resource utilisation and reduce energy consumption in-terms of product, process and policies is discussed by Bansal et al. (2000). These days business is beyond profit making due to economic globalization and pressure from the public. Also, government laws and environmental standards force organisations to adopt eco-friendly operations. When our planet health is a concern, a sensible and responsible business requires objectives that fetch competitive advantage without harming the environment. So, industries are bound to develop ecoefficient operations under CSR (viable in economic, social and environmental aspects); thus shifting away from corporate financial responsibility. The corporates necessity for linking environmental strategy to competitive advantage is studied by Junquera et al. (2012). However, a complete implementation model needs further research for adopting holistic GSCM. Thus, in this paper to support the holistic implementation we collate, relate and explain the activities in the SC stages with the layers (levels) of industry. To be green the stages are linked to the various levels (firm, business, society, and environment) of implementation with regard to an industrial scenario. This way of linking SC stages and layers will provide insight on the micro aspects for the implementers to develop plan, and evaluate the GSCM, which may be unique in its sense of existence of a chain.

\subsection{Background for developing Parametric Matrix}

There still exists a dearth for a consolidated GSCM approach linking corporate social responsibility, environmental sustainability, and business to business partner interaction for being green among and within stages of SCM. The entire chains efficiency is defined as the overall efficiency of all the elements/stages in a value chain; for a green value chain or a sustainable chain this unified conscious efforts are mandatory. There is a need for analysis of a single unit/ one product/ commodity going through raw material sourcing, production, post processing distribution and warehousing, and reaching end user. From this point of the life cycle, the analysis needs to be done to assess re-usability, the feasibility to meet remanufacturing requirements, functionality for a new remake or compatibility to a new product. When these aspects are used to form a closed loop, the chain becomes a green value chain. The green value chain/sustainable chain will have its main objective as low carbon impact or high environmental friendliness even at throwaway stage. Further, a chain becomes a green value chain when green scores are attained in terms of activities at the Firm, Business, Social and Environment levels. The green scores are derived from factors linking SC stages to layers. The research thrust area to define GSCM on a holistic approaches were as follows: cost advantages by reducing resource wastages Porter and van der Linde, (1995b), Integration of flow / activities / process (Cooper, 1993; Heizer \& Render, 2004; Lamming \& Hampson, 1996), Integration of people and technological 
resources seen in Burt (1996) and Coordination of resources for across the value chain in Koh (2012). A detailed list of definitions reflecting the differences in defining SSCM (12 unique definitions) and GSCM (22 unique definitions) is given by Ahi and Searcy (2013). The various aspects of study on supply chain are detailed by Hassini et al. (2012b) and suggested a metric based framework for sustainability along with the various hurdles in its adoption. Though holistic, the metric suggested needs further detailing at implementation level which is depicted in our paper. Research attempting overall involvement to attain GSCM includes: empirical survey on automotive industry in India by Apratul (2009), entire supply chain integration by Srivastava, (2007), reverse logistics Hervani et al. (2005), holistic approach Harvard business review October 2004, and greening efforts. At the firm level activities have to be oriented towards green. Initiatives like systematic approach to overcome scepticism (at business level), use alternative and recycled materials in production, evaluating firm's functional activities for environmental inefficiencies, and effort to transform the firm's vision from a product centric to eco-friendly services, help build GSCM (Rothenberg and Zyglidopoulos, 2007; Sharma, 2000). In this review the need for Parametric Matrix for a green value chain is described with the focus is on developing models for green chain implementation for any product, specifically with reference to five main stages of an SC by Nidhi \& Pillai, (2011). A general supply chain has five basic stages/phases such as procurement, manufacturing, distribution, logistics and customer phases. Based on the ontological levels by Oral (2009), an attempt is made to define a parametric matrix by combining the stages of supply chain. This matrix highlights the need for coordination among strategic, tactical and operational interaction for being a green value chain. Our aim is to find the strategic fit for a green value chain where the industry and end-user are consciously striving for environmental well-being. This will serve as a social cause for generations, thus acting as a strong foundation for future green value product developments thereby assuring sustainability. Among the plethora of research, the work that emphasis on strategic aspects of GSCM compared to operational and tactical (business collaboration with suppliers, inbound and out bound logistics) decisions is still at emerging stages. A recent work by Mutingi (2013) covers a comprehensive review of green strategies and identifies the taxonomical frame work based on product, process, and supply chain relationship or collaboration. The strategic vision (profitability, cost effectiveness, market share, and productivity and delivery superiority) at the firm level will cater as the inputs for operational and tactical actions at business and social environment. On an ontological view Oral (2009) green strategic, tactical and operational aspects are considered for developing the parametric matrix. In this work, we combine social and natural environment ontologically under the term Corporate Social Responsibility (CSR) which deals with transparency, ethical issues, corporate governance, social responsibility, reverse logistics, reusability, remanufacturing, and waste reduction/(elimination). In this context, GSCM is defined as a tool for continuous improvement for an organisation to implement sustainability in day-to-day SC operations by incorporating social responsibility with public priorities and thus reducing supply chain disruptions (or enhanced resilience). GSCM must incorporate sustainable strategies with CSR to fetch the competitive advantage. A best performing SC will be in the frontier of CSR (high to low levels of sustainability) and SCM performance (responsiveness and cost). (i.e). A high cost implies high responsiveness.

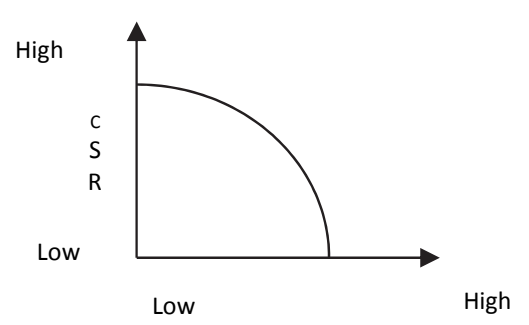

Fig. 1. CSR-GSCM frontier 
The efficiency and responsiveness in a chain is often considered as conflicting objectives. Enhanced the SC responsiveness implies more cost incurred, critically reflecting on the efficiency of ordinary SC. The CSR in GSCM thrust on the fact that, how a sustainable responsiveness, along the chain can be achieved. It can be inferred that a best performing green value chain will thus lie on the CSR-SCM frontier graph, as a result of the best strategies chosen for operation, shown in Fig.1.

This will necessitate a CSR centred core competency to be envisioned and developed by organisations. So, the various parameters for this continuous improvement are identified from the existing literature and presented in a matrix form. The priority of implementation will vary from one organisation to another and depends on product, process and environmental systems currently followed in industries. Different industries in varied parts of globe with wide-range of state of affairs in daily operations can opt from a common performance measure. The directions to develop the performance measure can be obtained from the Parametric Matrix. The proposed matrix is provided in Table 1.

This work attempts to bring various operating scenarios to a single hub of choices where a common goal of GSCM (sustainable business) can be achieved. Though variations exist in input model (varying environmental scenario of industries in existence), the external goal (output) for sustainability can still be achieved. The environmental harm (due to energy consumption, wasting resources) can be reduced by proper coordination and understanding among companies dealing with sourcing, product design, production, distribution and packing.

To avoid risk/disruptions, a firm has to maintain more number of suppliers with long term relationships to achieve GSCM. In the modelling context, role of information sharing in e-commerce and in retaining healthy relationship with supplier is considered critical by Bin (2007). To be a Sustainable Supply Chain Network (SSCN), the coordination among SC stages need a bi-level planning (Seuring, 2013; Sarkis, 2008; Zhu et al., 2008). These are network level and enterprise level Winkler, (2011a), with an integration of a special logistic provider to reduce resource waste in forward and reverse chains. As product life cycle begins, green chains can be made efficient through waste reduction. In material management perceptive, materials (manufacturing waste and post consumed product components) from one node form the input to another node to ensure eco-efficiency. In order to address the micro issues at distinct stages of SC we have incorporated Orals ontological perspective for layering in the parametric matrix.

\section{Parameter Matrix}

Supply chain disruption has been in interest of research since firms have been facing catastrophic failures with reasons tracing to even complex links of socio-technological systems coupled with inevitable accidents. The disruption analysis also needs a clear cut mapping at all levels and stages for managing misalignments across the chain. When supply chain disruptions occur or if Reverse Logistics (RL) is not completely structured, addressing the recycling and remanufacturing becomes a major challenge. In this context there is a need to thrust on the robustness of green value chain for its successful existence. Thus life cycle assessment becomes unavoidable when vulnerability of supply chains leading to disruptions / RL and environment are considered. Numerous studies have discussed various reasons (internal external) for supply chain disruptions and suggested best practices to overcome SC disruptions (Zsidisin, 1998; Grabowsk, 1997; Lin, 2006; Svensson, 2000; Martin, 2004; Harland et al., 2003; Tang, 2006a; Hendricks, 2005b; Coleman, 2006). A detailed list of supply chain vulnerability divers and an empirical study on SC disruptions with various case references are given by Wagner et al.,(2005). In a SCM, raw material procurement, manufacturing, distribution and warehousing form the main value chain operational components. But in an environmental and social context, the impact on air and water are of concern along with energy (electrical and water) which are important inputs for green evaluation. Therefore, a stage by stage analysis is taken for study at each level. Sameer Kumar et al. (2012) proposed the need for making business changes by listing the drivers 
of GSCM and drivers for implementing GSCM. Thus the authors reinforce the priority for sustainability in business than dealing with risk and un-certainty. But, the long term sustainability alone can bring profit and green value across the chain. Sudden switchovers for green value can result in unexpected failures since the chain elements need time to reach holistic consensus among levels and layers of SC. Failure or non-co-operation at any stage or element in the links of a chain can result in total disruption of sustainable objective in-spite of effort in other links to attain green value. In mapping a SC for a product for assessing the environmental impact like carbon foot print / efficiency and effectiveness this aspect become important. Thus, a framework of such a matrix is proposed to assist the analysis of Sustainability at a particular stage and to help holistic mapping on the chains sustainability. Since green value needs to be build up from present stage of organisations existence, a demarcation at such combinations of stage and level is quintessential for further build-up of green value across the entire chain, with an understanding of where one currently needs to focus.

Table 1

Parametric Matrix

\section{Layers of SCM}

\begin{tabular}{|c|c|c|c|c|}
\hline $\begin{array}{c}\text { Phases of } \\
\text { SCM }\end{array}$ & $\begin{array}{l}\text { Level } 0 \\
\text { Firm }\end{array}$ & $\begin{array}{l}\text { Level } 1 \\
\text { Business }\end{array}$ & $\begin{array}{l}\text { Level } 2 \\
\text { Society }\end{array}$ & $\begin{array}{c}\text { Level 3 } \\
\text { Environment }\end{array}$ \\
\hline 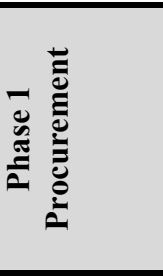 & $\begin{array}{l}\text { Green Resources \& } \\
\text { inbound logistics } \\
\text { Post consumed Material } \\
\text { Utilization rate } \\
\text { Environmental } \\
\text { Consensus in decision } \\
\text { making and activity }\end{array}$ & $\begin{array}{l}\text { Rating of supplier based on } \\
\text { environmental friendly } \\
\text { measures } \\
\text { Long-term and strategic } \\
\text { relationships }\end{array}$ & $\begin{array}{l}\begin{array}{l}\text { Awareness on } \\
\text { green sources }\end{array} \\
\text { Ethical Issues } \\
\text { Social responsibility }\end{array}$ & $\begin{array}{l}\text { Accountability } \\
\text { Sustainability }\end{array}$ \\
\hline 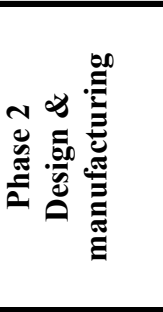 & $\begin{array}{ll}\text { - } & \text { Cradle to Cradle } \\
& \text { Design } \\
\text { - } & \text { Green methods } \\
\text { - } & \text { Innovation } \\
\text { - } & \text { Refurbishing }\end{array}$ & $\begin{array}{ll}\text { - } & \text { Lean practices } \\
\text { - } & \text { Cost effectiveness, } \\
\text { - } & \text { Green profitability } \\
\text { - } & \text { Productivity } \\
\text { - } & \text { Product returns }\end{array}$ & $\begin{array}{ll}\text { - } & \text { Life cycle } \\
\text { assessment } \\
\text { - } \\
\text { Rating of } \\
\text { products based } \\
\text { on environment } \\
\text { friendliness }\end{array}$ & $\begin{array}{ll}\text { - } & \text { Environmental } \\
\text { - } & \text { Enmitment } \\
& \text { Environmental } \\
& \text { efficienction } \\
\text { - } & \text { Marketability of } \\
\text { remanufactured } \\
\text { goods }\end{array}$ \\
\hline 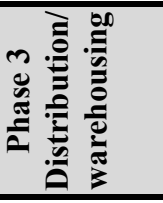 & $\begin{array}{l}\text { Green transportation } \\
\text { Shelf life Assessment } \\
\text { Product flexibility }\end{array}$ & $\begin{array}{l}\text { Green fuel usage } \\
\text { Environment Management } \\
\text { System } \\
\text { Order cycle time } \\
\text { Delivery flexibility } \\
\end{array}$ & $\begin{array}{l}\text { Pollution control } \\
\text { Awareness programs } \\
\text { Transparency }\end{array}$ & $\begin{array}{l}\text { Environmental } \\
\text { commitment } \\
\text { Accountability based on } \\
\text { Carbon foot print }\end{array}$ \\
\hline 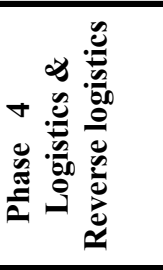 & $\begin{array}{l}\text { Disassembly \& recovery, } \\
\text { Recycling and Reuse } \\
\text { Time to take back } \\
\text { Information sharing rate } \\
\text { Material flow rate }\end{array}$ & $\begin{array}{l}\text { Responsiveness } \\
\text { Superiority } \\
\text { Mode of collection } \\
\text { Responsibility of } \\
\text { service providers }\end{array}$ & $\begin{array}{l}\text { Sustainable supply chain } \\
\text { (land, energy, air, water } \\
\text { and hazardous elements } \\
\text { are to be considered) }\end{array}$ & $\begin{array}{l}\text { Environmental } \\
\text { commitment } \\
\text { Accountability based on } \\
\text { Carbon foot print } \\
\text { Environmental impact } \\
\text { indicators }\end{array}$ \\
\hline 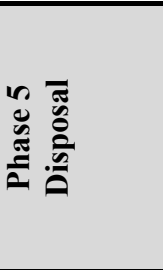 & $\begin{array}{l}\text { Minimum waste, } \\
\text { Dismantling to recover } \\
\text { reusable parts, } \\
\text { Work with regional } \\
\text { recycling experts, } \\
\text { Increase market viability } \\
\text { with timely recycling }\end{array}$ & $\begin{array}{l}\text { New combinations of } \\
\text { knowledge about product } \\
\text { characteristics, process \& } \\
\text { material characteristics } \\
\text { Information } \\
\text { utilization rate }\end{array}$ & $\begin{array}{l}\text { Governance } \\
\text { Adaptation (re- } \\
\text { engineering, reuse, } \\
\text { clean energy, } \\
\text { energy efficiency) } \\
\text { Social cost }\end{array}$ & $\begin{array}{l}\text { Pollution } \\
\text { Impact on } \\
\text { Environment } \\
\text { Bio-degradability } \\
\text { Health issues }\end{array}$ \\
\hline
\end{tabular}

The study on evaluation of GSCM practice Lin (2012) based on review of best practices in GSCM indicates thrust areas as green purchasing, green design, collaboration with suppliers and customers, 
and product recovery and reuse of used products. These activities are the micro factors reflecting macro operational factors of being a green SC. The earlier literature covering various surveys in industries of China, and Taiwan shows long term relationship has benefited like (1) reduced raw material waste and associated costs of disposal; (Verdecho, 2014) (2) reduced transportation costs and reduced compliance costs; (3) reduced risk of business interruption due to regulatory violation, boycott, supplier interruption, spill, toxic release, etc.; (4) increased customer retention rate and as a result increased market share. The green management is found to gain more positive influence from green awareness than just individual positive effects in logistics (Choi \& Zhang, 2011), manufacturing or disposal. Their work highlights firms' business from green logistics-strategic perceptions to be green along with the integration of green management performance with factors such as awareness and size of the firm. The review in this paper, attempts to fill the gap of previous works and sustainable chains various dimensions of connectivity to CSR, manufacturing, and green logistics to help future researchers to contribute models for implementing GSCM. As we attempt to capture the micro aspects, it is revealed that at each level there are strategic and tactical decisions overlap at stages, which may become critical when put in practice. This makes the model more complex for analysis with various interactions within and among the different stages of the value chain.

To enable ease of understanding, the parametric matrix factors (micro and macro) are related to previous literature and are presented under four levels (layers) of SCM. Thus to facilitate ease of understanding, we present the references considering the organisation with a strategic vision and allied business activities. Corresponding to each activity tactical level under CSR, and parallel social and natural environmental factors are identified. The lack of strategic alignment of organisation with social responsibility in research is also pointed out by Filho et al. (2010). Fleischman et al. (2000), suggested the difficulty of integrating forward and reverse logistics; examples include reusable soft drink bottles, LPG bottling plants collecting the empty cylinders for refilling from distribution centres, etc. Table 1 gives the detailed description of parameters with micro elements to be considered for GSCM implementation. The parametric matrix helps to identify the capabilities to improvement opportunities in-order to plan workable goals, monitor collective progress, and decision for early supplier involvement. Sustainable development broadens beyond an individual's responsibility and it involves the integration of politics, economy, society, environment and technology. These factors are taken into account in the development of parametric matrix. Each aspect is supported by accurate and timely information sharing among the interacting cells on the Parametric Matrix (PM). The cell depicts the activities under various interacting elements of the matrix to form a green chain. The relevant literature is listed in Table 2 and explained in the following Sections. Planet health being a concern, a sensible and responsible business requires objectives that fetch competitive advantage without harming the environment. So industries are bound to develop eco-efficient operations under CSR (viable in economic, social and environmental aspects) thus shifting away from corporate financial responsibility. The corporate's necessity for linking environmental strategy to competitive advantage is studied by Junquera \& del Bro (2012). However a complete implementation model needs further research for adopting holistic GSCM. Thus, in this paper to support the holistic implementation we collate, relate and explain the activities in the SC stages with the layers (levels) of industry. To be green the stages are linked to the various levels (firm, business, society, and environment) of implementation with regard to an industry. This way of linking SC stages and layers will provide insight on the micro aspects for the implementers to develop plan, and evaluate the GSCM, which may be unique in its sense of existence of a chain.

\section{a. Background for developing parameter matrix}

This section covers the basic factors for GSCM implementation identified from various literatures. This forms the background for parameter matrix formation and also shows which all researches have focused on what all aspects of GSCM. Hence providing birds eye view of various research done over years in order to development holistic perceptive towards GSCM. 
Table 2

References of Literatures related to Factors of Parameter Matrix

\begin{tabular}{|c|c|c|}
\hline GSCM factor & Author \& Year & Relative Aspects in the literature on GSCM \\
\hline 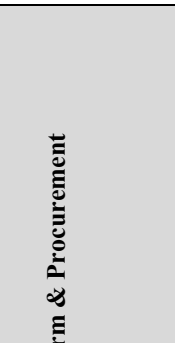 & $\begin{array}{l}\text { Sakris (2006); Yu et al. (2008) } \\
\text { Dong (2005); } \\
\text { Rao and Holt (2005); } \\
\text { Bowen et al. (2001); } \\
\text { Thierry et al. (1995); } \\
\text { Sakris (2003); } \\
\text { Zsidisin \& Siferd (2001); } \\
\text { Zsidisin \& Hendrick (1998). }\end{array}$ & $\begin{array}{l}\text { Vendor selection and in bound logistics with environmental concerns. } \\
\text { Inventory, procurement in reverse chain, purchasing \& logistics. } \\
\text { Hazardous material minimization, alternate material utilization that are } \\
\text { eco-friendly (South East Asian context) Defined green supply in context } \\
\text { of organization's purchase } \\
\text { Sourcing of used products } \\
\text { purchase of materials that are } \\
\text { recyclable or reusable or already recycled waste reduction gives the key } \\
\text { factors in environment friendly purchasing }\end{array}$ \\
\hline 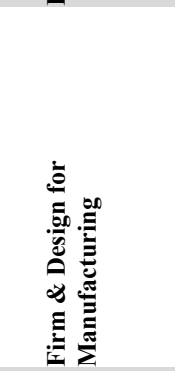 & $\begin{array}{l}\text { Aras et al. (2008); Lenox et al. (2002); Sakao } \\
\text { (2009); Klassen (2000,2004); } \\
\text { King \& Lenox (2002); } \\
\text { Tibben-Lembke \& Rogers (2002); } \\
\text { Bovea and Wang (2007), } \\
\text { Aksoy \& Gupta ( 2005); } \\
\text { Kim et al. (2006d); } \\
\text { Florida (1996); } \\
\text { Defee et al. (2009); Guide \& } \\
\text { Wassenhove (2001). }\end{array}$ & $\begin{array}{l}\text { Integrates QFD, TRIZ, LCA, Life Cycle Costing w.r.t Environment } \\
\text { impact, recycling, reverse logistics, Remanufacturing. } \\
\text { Environment management systems and integration } \\
\text { Environment conscious manufacturing and innovative approaches }\end{array}$ \\
\hline 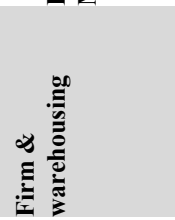 & $\begin{array}{l}\text { Halldorsson et al. (2009); } \\
\text { Lieckens and Vandaele (2007); } \\
\text { Klassen \&Whybark (1999); } \\
\text { Cordano \& Frieze (2000); } \\
\text { (Johansson 2002; Zhu, Sarkis \& Lai, 2007); }\end{array}$ & $\begin{array}{l}\text { Stochastic RL MILP network } \\
\text { Environmental friendly technology usage, performance measure } \\
\text { Environment Managers' attitude to pollution control, regulations, source } \\
\text { reduction Techniques } \\
\text { Eco design } \\
\text { Green purchasing and eco design definitions can be found in Zailani }\end{array}$ \\
\hline 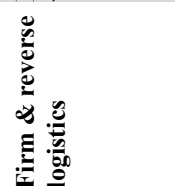 & $\begin{array}{l}\text { Veerakamolmal \& Gupta, (2000); } \\
\text { Kroll \& Hanft (1998); } \\
\text { Ferguson \& Browne (2001); } \\
\text { Sbihi \& Eglese (2007); } \\
\text { Aronsson \& Brodin (2006). }\end{array}$ & $\begin{array}{l}\text { Product stewardship, Reverse logistics, combinatorial optimisation, } \\
\text { Decision modelling in recycling and disassembly, Evaluation chart, End of } \\
\text { Line Vehicles, joint set up cost models, Green logistic optimisation }\end{array}$ \\
\hline 章 & $\begin{array}{l}\text { Lee et al.(1995); Craig e.al (2008); Guide et } \\
\text { al.(2000); Beamon (1999); Jayaraman (2006); } \\
\text { Srivastava (2007); Moyer and Gupta } \\
\text { (1997);,Thierry et al. (1995). }\end{array}$ & $\begin{array}{l}\text { Stochastic product recycling, planning the disassembly, recycling in } \\
\text { electronic industry } \\
\text { Product recovery management, disposal of hazardous waste }\end{array}$ \\
\hline 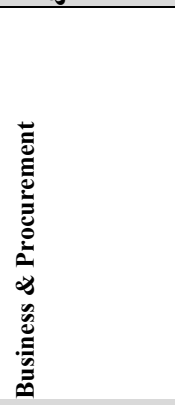 & $\begin{array}{l}\text { Carter et al. (1998); } \\
\text { Handfield (2002); } \\
\text { Min \& Galle (2007); Rao (2004); } \\
\text { Arpatul shukla (2010); } \\
\text { Walton, et al.. (1998); } \\
\text { Klassen \& Vachon (2006); } \\
\text { Zhu \& Sarkis (2004); } \\
\text { Hall (2000, 2001); } \\
\text { Mohammad Asif Salam (2008);Klassen \&Whybark } \\
\text { (1999); } \\
\text { Florida (1996). }\end{array}$ & $\begin{array}{l}\text { Defines green procurement } \\
\text { Green supplier evaluation } \\
\text { Waste reduction, environmental performance } \\
\text { AHP in Green supplier selection } \\
\text { Supplier integration for environmental friendly practise } \\
\text { Relationship between the interacting stages (customer-supplier, supplier- } \\
\text { suppliers) } \\
\text { Explores product performance based on purchase price, the } \\
\text { organization's environmental concerns, trading } \\
\text { partners, and health and safety } \\
\text { issues in context of electronic industry (Thailand) } \\
\text { looked at customer-supplier relationships for env. improvement }\end{array}$ \\
\hline 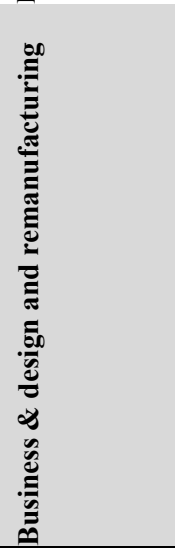 & $\begin{array}{l}\text { Staikos \& Rahimifard } \\
\text { (2007a,b); } \\
\text { Srivastava (2007); } \\
\text { Fiksel (1996); } \\
\text { Mohammad Asif Salam,(2008); } \\
\text { Chiou et al. (2011); } \\
\text { Hsu, C.W. \& Hu (2008); }\end{array}$ & $\begin{array}{l}\text { Reuse, recovery, remanufacturing of post consume shoe- case } \\
\text { analysis } \\
\text { LCA importance } \\
\text { Product and services with environment consciousness } \\
\text { OEM and ODM adopting green procurement } \\
\text { Product Process innovation (PPI) with environment } \\
\text { responsibility, Competitive advantage via PPI } \\
\text { Product database, product testing report on recycling }\end{array}$ \\
\hline
\end{tabular}




\begin{tabular}{|c|c|c|}
\hline GSCM factor & Author \& Year & Relative Aspects in the literature on GSCM \\
\hline 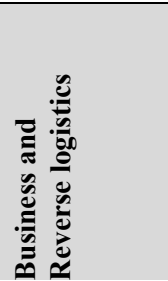 & $\begin{array}{l}\text { Tibben-Lembke (2002); } \\
\text { Guide and van Wassenhove (2003a); Rao \& } \\
\text { Holt (2005); } \\
\text { Sakris (2003); Srivastava (2007); } \\
\text { Klassen \& Vachon (2003); } \\
\text { Fleischmann et al. (1997,2000); } \\
\text { Rogers (2001); } \\
\text { Christine Rosen (2001); }\end{array}$ & $\begin{array}{l}\text { Reverse logistics and Product life cycle } \\
\text { Business aspects of various rev.log systems } \\
\text { Importance of strategies in RL } \\
\text { Reverse logistics economy \& environment gains } \\
\text { Product recovery and relationship in business } \\
\text { Natural capitalism, Corporate greening }\end{array}$ \\
\hline \& & $\begin{array}{l}\text { Koplin et al. (2007); } \\
\text { Amar Ramudins (2010); } \\
\text { Cordeiro \& Sarkis (1997); } \\
\text { Wu et al. (2008); Lee (2008). }\end{array}$ & $\begin{array}{l}\text { Design the network for lost cost distance and cross docking } \\
\text { Green practices of the organization } \\
\text { Partnering Strategy for competitive advantage }\end{array}$ \\
\hline 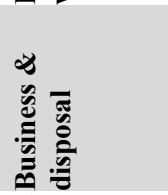 & $\begin{array}{l}\text { Srivastava (2007); } \\
\text { Klausner \& Hendrickson } \\
\text { (2000); Linton et al. (2007); } \\
\text { Cairncross (1992); } \\
\text { Jayaraman (2006). }\end{array}$ & $\begin{array}{l}\text { Secondary market from reusable products, remanufacturing, buy } \\
\text { back policy } \\
\text { Mechanisms like recycling and sorting of reusable items } \\
\text { Schemes for collection, sorting and reuse } \\
\text { Collection and repair mechanism }\end{array}$ \\
\hline 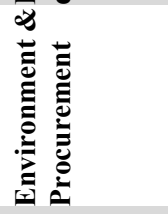 & $\begin{array}{l}\text { Lamming \& Hampson (1996); Florida (1996); } \\
\text { Clift \& Wright (2000); Geffen \& Rothenberg } \\
\text { (2000); Hall (2000); Green et al. (1998); } \\
\text { Bowen et al. (2001a); Melnyk et al., 2003) }\end{array}$ & $\begin{array}{l}\text { Extend the production goal to purchasing aspects, purchase } \\
\text { function to include reuse } \\
\text { corporate social responsibility, minimize risks to their reputation, } \\
\text { reduce waste and increase flexibility in response to new } \\
\text { environmental regulations in context of green supply }\end{array}$ \\
\hline 車 & $\begin{array}{l}\text { Wagner et al. (2001); } \\
\text { Sharma \& Vredenburg (1998); Olugu et al. } \\
\text { (2010). }\end{array}$ & $\begin{array}{l}\text { Environment \&Economy - empirical investigation } \\
\text { Environmental Performance/effects based on activities of } \\
\text { environment and co-corporate }\end{array}$ \\
\hline ¿ & $\begin{array}{l}\text { Kainuma \&Tawara (2006); } \\
\text { González-Benito } \\
\text { \& González-Benito (2006). }\end{array}$ & $\begin{array}{l}\text { Return on assets, customer satisfaction } \\
\text { Green Logistics }\end{array}$ \\
\hline 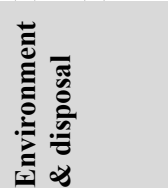 & $\begin{array}{l}\text { Liang et al. (2006); } \\
\text { Papadopouslos \& Giama (2007); } \\
\text { Chien \& Shih (2007); Winn \& Angell (2000). }\end{array}$ & $\begin{array}{l}\text { Environment effects /environment performance indicators based } \\
\text { on Waste disposal and resource utilization } \\
\text { Management performance indicators (policy measures, corporate } \\
\text { image,) } \\
\text { Corporate greening policies, implementation }\end{array}$ \\
\hline \& & $\begin{array}{l}\text { Kolk \&Tudder (2002); Emmelhainz \& Adams } \\
\text { (1999); Simpson and Power (2005); } \\
\text { Minton \& Rose (1997); }\end{array}$ & $\begin{array}{l}\text { Supplier development with CSR, need for market value } \\
\text { assessment, creating awareness. } \\
\text { Proactive attitude towards environmental behavior. }\end{array}$ \\
\hline \& & $\begin{array}{l}\text { Feldman et al.(1997); Kolk \& Tudder (2002); } \\
\text { Emmelhainz \& Adams (1999); } \\
\text { Cruz (2008). }\end{array}$ & $\begin{array}{l}\text { interplay of the heterogeneous decision-makers and compute the } \\
\text { equilibrium pattern of product outputs, transactions, prices, and } \\
\text { levels of social responsibility activities }\end{array}$ \\
\hline 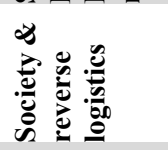 & $\begin{array}{l}\text { Johnson (2001); } \\
\text { Norrman \& Jansson (2004); } \\
\text { Meade \& Sarkis (2002). }\end{array}$ & $\begin{array}{l}\text { 3PL, complexity in forward and reverse flow, societal benefit } \\
\text { handling operations of storage \& transport }\end{array}$ \\
\hline 竞 & $\begin{array}{l}\text { Chien \& Shih (2007); } \\
\text { Papadopouslos \& Giama (2007); } \\
\text { Florida \& Davison (2001); } \\
\text { Batterman \& Amann (1991); Buck de et al. } \\
\text { (1999); Quinn, (1999); Qio et al.( 2001) } \\
\text { Fineman (1996). }\end{array}$ & $\begin{array}{l}\text { Policy measures for better environment management, community } \\
\text { relations and awareness, measure of approval rate of management } \\
\text { systems } \\
\text { Keeping track of emissions and regulatory compliances, } \\
\text { community satisfaction } \\
\text { decision-makers, producers, retailers, \& consumers associated } \\
\text { with the demand markets to workout disposal plans emotional } \\
\text { attribute of managers towards environment }\end{array}$ \\
\hline
\end{tabular}


Efforts for collaboration and co-ordination among the decision makers of supply chain to achieve a common goal are impossible without sharing the information earnestly. The thrust on benefits of collaboration not only reduce waste in the supply chain, but also increase market responsiveness, customer satisfaction, and competitiveness among all members of the partnership (Vachon \& Klassen, 2006; Porter \& van der Linde, 1995b; Ashford (1993) and Kemp (1993). Also training programs on SCM technology updation help in knowledge sharing and collaborative activities that reduce uncertainty. Extend of willingness to change, lack of awareness and other sources of resistance are frequently associated with lack of investment in Social Responsibility activities. Investment in environmental technology in the recent past include activities like reduced packaging, joint recycling of parts and components, and process changes that reduce the use of hazardous materials Klassen \& Vachon, (2003). Section 3.1 deals with important aspects of procurement with respect to GSCM and Section 3.2 on GSCM manufacturing. Section 3.3 deals with logistics for GSCM.

\subsection{Procurement}

Procurement related activities on the perception of a firm, business and CSR, and relevant literature are discussed in this section. Here the CSR covers social and environmental aspects related to a GSCM from the Parametric Matrix point of view. The staff awareness on green capabilities of supplier and ensuring these features on bidding will assure green procurement in the industry. The influence of green purchasing and its financial consequences are accessed via product life cycle (PLC). PLC incorporates development of an inventory, impact of materials, products and processes, and improvement analysis aspects. Such integrated proactive purchasing focuses on whole-chain financial optimization which typically results in 10 - 20 percentage cost saving and a substantially greater increase in profits (D 1996; Burt 2003). Organizations are expanding their activities to comprise the Corporate Social Responsibilities of their partners within the supply chain (Kolk 2002; Emmelhainz 1999) to have better control on competitive advantage towards strategic fit. Simpson et al. (2007), indicated that the supply relationship is capable of leading to programs of collaborative waste reduction, environmental innovation at the interface, cost-effective environmental solutions, rapid development and uptake of innovation in environmental technologies, and allow firms to better understand the environmental impact of their supply chains (Lamming \& Hampson, 1996; Florida, 1996; Clift \& Wright, 2000; Geffen, 2000; Hall, 2001). A study by Svensson indicated that a sound environment policy can foster a good relationship between a company and its stakeholders and can create a competitive advantage Svensson (2000). The green attempt has served companies to have more market share due to enhanced reputation. The studies from China and Taiwan depict the green initiatives that have resulted in cost effectiveness due to lasting relationship with suppliers. This results in innovative and cost effective end products which are realized at business layer by rating the sup-plier for GSCM. The accountability and sustainability are realized at environment layer through the Corporate Social Responsibility at social layer. The supplier selection using analytic network process (ANP) to reduce environmental impact based on certain evaluation criteria is a breakthrough in GSCM, discussed by Tseng et al. (2013). Based on the insights on procurement of green goods, supplier experiences green limitations, as discussed by Morgan \& Linda, (1997), which leads the business towards a controlled adherence and to be green.

\subsection{Manufacturing and Remanufacturing}

In supply chain management the manufacturing is the most important element of forward chain after the procurement. Recycling, reusing and remanufacturing are possible only with reverse logistics and proper management of Dismantling Centre with pivotal control at Collection Centre. If the customer returns the product to the manufacturer it becomes a closed chain. But, normally the reverse logistics along with collection and dismantling centre tries to identify the products/material that are reusable at each stage of the forward chain. For instance, the packing material finds use at the packing section of production plant and despatch material at logistics, post consumed product when dismantled will have materials usable at shop floor. In the context of production, Winkler (2011b), insists on the need for 
holistic approach on economic and environmental consensus among the interacting companies. This indirectly points to the need for holistic approach of the chain to be green. Mostly, Mathematical model based research is less in the context of green. However, a few recent works indicate that inventory management towards sustainable development which is a budding research area. They discuss on cap and trade systems, regulations and emission control to reduce Carbon Foot Print into Economic Order Quantity (EOQ) model (Saif Benjaafar \& Daskin, 2013; Hua et al., 2011; Bonney \& Jaber, 2011). There have been attempts by researchers to comprehend on environment conscious manufacturing since the end of $20^{\text {th }}$ century onwards, (Gungor \& Gupta, 1999; Lambert et al., 2011). These days Environmentally Conscious Manufacturing extends from energy efficient manufacturing to the product recovery and reusability till End Of Life (EOL). Cradle to cradle design has not only helped customers but also manufacturers for a responsible environmental friendly disposal. The early works relating environmentally conscious design and manufacturing (Zhang et al., 1997), green manufacturing with product recovery Sakao(2009), Remanufacturing Bras \& McIntosh, (1999) and Production planning and control for remanufacturing Guide (2000) provide important basic insights with regard to green production than the conventional interest on cost, functionality and manufacturability alone. Later, Design For Environment (DFE) (Fiksel \& Fiksel, 1996; Cristofari, 1996; Deshmukh, 2010; Wang, 2003; Bevilacqua,2007), Quality Function Deployment (QFD), QFD II, Zhang, (1999); QFD III, Mehta (2001); and LCA (Zhang, 1999; Mehta, 2001; Sakao 2009 ;Bovea \& Wang, 2003 ; Bovea, 2012) were the methods tried out for reasonable reality to achieve green in manufacturing context and today we find the combinations of these methods employed by researchers for better pragmatic solutions to achieve greening. The generic term Design For X (DFX) is discussed as design for manufacturing, design for quality, etc. (Meerkamm, 1994; Veerakamolmal, 2002; Kuo 2000). A recent exhaustive literature survey covering the above methods in remanufacturing and reverse logistics is given by Ilgin \& Gupta, (2010). The main challenges for SC has been in deciding how to integrate remanufacturing and manufacturing, pricing of products, managing refurbishment facility and coordinating manufacturing with recycling centres.

\subsection{Environmentally Responsible Logistics (Green logistics and Reverse logistics)}

The business boardrooms now think of sustainable positioning of their organisation and cash flow management today, which is mainly dependent on logistics along with various vagaries in operation. The term Logistics describe transportation, storage and product handling while in transit from source to point of consumption. The transportation and logistics have major futuristic concerns in terms of type of fuel, mitigation of environmental impact, overcoming the transport infrastructural bottlenecks, convergence of SCM to regional networks. The logistics providers have heroic role whenever SCM flexibility and responsiveness are considered. Also, they are at stake when green indices are considered. Often the carbon emissions costs are charged at the causer. This calls for tracing the carbon foot print. In the near future, in order to assess full environment impact, the logistics providers will need to trace and document all associated emissions like nitrogen oxides, noise pollution, etc.

Logistics has been the fundamental activity in determining business performance for more than 50 years. Along with carbon emission reduction, five major drivers for green logistics are optimised logistics flow, improved corporate image, reduced logistics cost, achievable compliance regulation and satisfied customer (Mckinnon, 2011). Logistics service encompasses activities like warehousing, transportation, inventory management, order processing, and packaging for their customers (Delfmann, 2002; Jay,2008). The green logistics has been a growing area of study in an attempt to make SC sustainable (Skjoett-Larsen 2000; Murphy, 2003; Sarkis, 2004; Rodrigue, 2001; Rondinelli \& Berry, 2000). Furthermore, while some researchers focused on environmental practices in logistics (Murphy, 2003; $\mathrm{Wu}, 1995)$ a few others focused on drivers for environmental practices in logistics industry (Murphy, 2003; Paul \& Poist, 1995; Paul, 1994 ; Szymankiewicz, 1993). An empirical study on drivers was conducted by Wong and Fryxell (2004). Logistics has been gaining importance in the last decade, due to the critical role played by the service providers to enhance responsiveness across the forward 
chain. The service providers of reverse logistics has much more responsibility in terms of collecting post-consumer goods to dismantling centre and make them available if usable at various user points in the reverse chain/forward chain. There have been studies trying to integrate forward (inbound and outbound) and reverse chains for better economy. This integration also has been proving less harmful to the environment and led to the exploration for more innovations in green logistics. Some of the innovations emerged in green logistics across countries recently include, clean vehicles run with renewable resources, track emission levels, restriction zones (to maintain low emissions), co-ordinated transport, cooperation with customers/supplier in order to reach environmental targets, environmental education/training/information for employees of both in-house and associated players, congestion mitigation, charging information, utilisation of water resources, use of route planning software, etc. A detailed discussion in this context is given by Jumadi and Zailani (2010). The role of ICT in greening the logistics is being practiced by small Logistics Service Providers (LSP) (zailani, 2010; Amran, 2011). The green logistics in its evolution, imparts a huge scope for GSCM as a research area. Based on the number of employee, company history, and capital size, the operational initiatives vary among small Logistics Service Provider (LSP) to Third Party Logistics (3PL). The 3PL shows more awareness towards green initiatives (Evangelista 2011; Lin, 2008). An empirical study by Lin and Ho (2008), analyses 162 samples and they were able to identify factors influencing green innovations as technological, organizational, and environmental. Their study claims the need for co-existence of organizational encouragement, quality of human resources, environmental uncertainty and governmental support to adopt green practices in logistics. This holistic approach is reflected in our Parametric Matrix.

Reports indicate that SC design of logistics location will be based on reduction of carbon and cost of energy, with major challenge in decreasing carbon cost than fuel cost to drive vehicles. Green logistics identifies ways to reduce the environmental impact (via decarbonising or ware-housing with green logistics) of transport and logistics activities which contain intermodal solutions Mckinnon (2011). Advances in tools for assessing the carbon footprint of activities (Mckinnon,2011; Kristin \& Lieb,2010; Piecyk, 2015) green transport management (Kristin \& Lieb, 2010), and green logistics system design (Aronsson, 2006; Kohn \& Brodin, 2008; Irina, 2011) are the recent areas of research interest. An analytical framework of green logistics is contributed by Mckinnon ( 2011).

\section{Different Modeling Approaches in GSCM}

GSCM mathematical modelling is still a challenge and finds a prodigious scope in GSCM holistic approach. There was only a handful of research papers contributed to this aspect. There have been various approaches to modelling and analysis GSCM. Mainly this paper address on numerical model on QFD, LCA, survey based analysis, and models based on Cost/profit.

\subsection{GSCM mathematical Model}

Most of the models are restricted to areas like supplier selection, reverse logistics, inventory planning in remanufacturing, recycled product integration in remanufacturing, integration of forward reverse logistics and LCA with QFD or DFX. Though there are attempts to reduce environmental effects in terms of Carbon Foot Print, very few quantitative models are available till date. But it is observed that the number of works is tremendously increasing in the empirical form; each adding to the new dimension and insight to be green in the business operations. Thus in this paper a strong base for operational activities spreading from Firm to Business and extending the Corporate Social Responsibility (CSR), to society and environment for future researchers to develop models that are implementable from any stage of existence is discussed. The main hurdles for holistic GSCM may be due to lack of cooperation from Industries, awareness and urgency of need by Industries especially in developing countries, Industry Academic Gap, tools for quantifying environmental impact, and environmental conscious CSR. 
In this section deliberations are made to identify various models in order to achieve competitive advantage and to credibly demonstrate the reduction of emissions. Bojarski et al. (2009) proposed a MILP model that integrates LCA in order to find the active link and associated environmental impact. Hugo and Pistikopoulos (2005) discuss the integrated multi-objective model along with LCA for network design. Some of the factors considered for modelling are capacity at distribution and warehousing by Ramudhin \& Paquet (2009) and expansive allocation by Hugo (2005). A holistic approach to GSCM modelling is more visible in Ramudhin \& Paquet (2009). Sheu et al. (2005) discuss the integration of forward and reverse logistics model using MILP. Five-Stage forward functions (raw material supply, manufacturing, wholesaling, retailing, and end-customers) and a five-stage reverse logistics chain (recycling plants, a disassembly plant, secondary material markets, and final disposal locations for waste) were proposed for integration by the authors. Their result showed an increase of about 21.1 percentage in net profit by implementing the suggested integrated supply chain model. Abdallah et al. (2014), conspires an MIP model thrusting for supplier to be green in activities for GSCM. Throughput and storage capacity of the manufacturing site and distribution centres and nonconsideration of flexible mechanisms of emission trading were the thrust areas discussed by Diabat and Simchi-Levi,(2009) and Ramudhin et al. (2008). Each manufacturer faces three criteria: the maximization of profit, the minimization of emission, and the minimization of risk. Dobos \& Richter (2006) Studied the production/recycling model with quality consideration.

\subsection{Empirical Studies}

In this section, studies related to purchase, logistics and policies for greening the activities of a supply chain are depicted. The empirical papers on manufacturing and disassembly and sustainable supply chain is discussed in review is given by Ilgin \& Gupta (2010) and Seuring et al., (2008). The Empirical studies in the context of aligning competitive advantage strategy considering environmental impact is given by Brio (2012). An Empirical Investigation based on product performance, purchase price, the organization, environmental concerns, trading partners, and health and safety issue in adopting green Procurement is given by Salam (2008). Green practices to attract more client using green logistics (Huang \& Li 2010; Chang \& Fong 2010), green management and business, Green management and firm's performance are discussed by many authors (Zeng et al.,2010; Wu et al., 2010; Wanger, 2005; Szy-manski \&Tiwari, 2004; Zhu \& Sarkis, 2004). Research of Evaluation Model on Enterprises Green Degree of GrSCM is suggested by Zhang(2011). Hendricks \& Singhal (2005) studied the impact of external internal and eco design practices on GSCM. A green performance assessment of Chinese industries is given by Li (2011). An Empirical study of manufacturing aspects is seen in Holt (2009). There have also been studies on the influence of regulations and governmental policies to enforce green attempts by organisations (Emmelhainz 1999 ; Lamming \& Hampson 1996 ; Fiksel \& Fiksel 1996; Clift \& Wright 2000; Charlette A. Geffen 2000 ; Hall \& Vredenburg 2005). The need for firms to adhere to green practices Sarkis \& Cordeiro (2001) under the pressures (regulatory compliance) Florida \& Davison (2001) and the need for policy/regulation percolation domestic, government, and international dimensions (Zhu \& Sarkis, 2008) are most critical for a Green SCM implementation. Such encouragement and enforcement (Levy, 2002; Papadopoulos, 2007) (based on building construction and insulation material) for green policy regulations play a crucial role in driving environment conscious business practices even in day to day operations.

\subsection{Cost/Profit models}

In an attempt to be compatible to environment regulations, organisations can save on cost through optimising resource utilisation, waste minimisation, and productivity enhancements etc., (Porter \& Linde, 1995a; Hervani et al., 2005; Wilkerson, 2005). The remanufactured products incur about 4060 percentage of the cost of original product and this results in environmental and economic advantage (Dowlatshahi, 2000; Giuntini, 2003). Studies show that 14 million tons of material savings per year worldwide, and an estimated 120 trillion BTUs/year of energy is saved from remanufacturing globally 
(Giuntini, 2003). The influence of incentives to encourage product returns via buy-back campaigns are studied by Klausner and Hendrickson (2000) and to facilitate the collection points near customer for ease of collecting back the post consumed goods are studied by Aras and Aksen (2008). In another work by Kaya (2010), the optimal value of the incentive to offer to remanufactured and virgin material returns, and the optimal production quantities of original and remanufactured products in a stochastic demand condition are determined. Akçali \& Bayindir (2008) and Karakayali et al. (Karakayali et al. 2007; Kaya 2010) are the analytical model contributors to cost and incentive systems in remanufacturing context. The feasible assignment of selected disassembly tasks with precedence criteria of various alternatives in reverse processing for profit orientation through Mixed integer formulation is discussed by Altekin et al(2008). With right combinations five tasks such as: 1) selection of parts with demand to generate revenue, 2) line balancing for disassembly lines 3) opening of appropriate work stations 4) cost of associated stations 5) Cycle time, the model solves for optimum profit. The model is capable to handle about 320 disassembly tasks. Alshamrani et al.(2007) considered a unique multi-stop vehicle routing problem for return container collection related to blood distribution as a dynamic problem incorporating penalty cost for not picking the returns.

Lin (2012) discussed on Firm's economy via cost reduction through material purchasing, energy consumption, waste treatment measures and negative impact on firm's economy (Zhu \& Sarkis, 2004; Zhu et al., 2007) are limited due to fewer quantitative models. The effect of operational activities on environment is given by Sharma \& Vredenburg, (1998) and importance to measure environmental effects, substantiate the need for a quantitative model to measure environment impact are at research stage till date. The investment recovery is a concept extendible over closed loop supply chain and can be achieved via eco-friendly profit enhancing strategies like sale of excess inventory, scrap and capital equipment. Carter et al. (2000) narrates the profitability in adopting green practices. In the 1990s, a number of empirical studies attempted to correlate corporate responsibility with society via financial performance (Clarkson, 1991; Kotter and Heskett,1992; Collins and Porras, 1995; Waddock and Graves, 1997; Berman et al., 1999; Ro-man et al., 1999) are given by Cruz (Tina Wakolbinger 2008), which could form a base for formulating models for assessing profit. Thus the economic implications of Environment management in the integrated context are an emerging research area in supply chain cost-profit analysis. Organisations today are forced by regulations to adopt social responsibility other than profit alone. This will help in achieving far reaching socio-economic benefit for the developing nations.

\section{Corporate Social Responsibility (CSR)}

For more than 160 years social equity and economic growth were perceived with much quest, but during the Earth Submit 1992 the carrying capacity of natural system sustainability was brought to widespread acceptance (M., 1993). CSR traces its origin from corporate social management, although widely realized among corporate stakeholders, academicians, and consultants in the recent past. The broad guidelines are discussed by Marrewijk et al. (2003) and World Commission on Environment and Development (1987). Salzmann defined CSR as, Profit-driven corporate response to environmental and social issues that are caused through the organizations primary and secondary activities (Oliver, 2005). CSR is also defined as transparent business practices that are based on ethical values, compliance with legal requirements, and respect for people, communities, and the environment (Chandler, 2001). Also bodies/associations such as business for social responsibility in US, International Business Leaders Forum in UK, have evolved for ensuring CSR. It is also reported in Catalyst consortium, July 2002 that in developing countries like India, Indonesia, Brazil, Egypt, and the Philippines, there exist business associations dedicated to CSR. In India studies have shown that there 80 percent CSR penetration compared to their counter parts of world (Chambers, 2003). The industries adopt CSR for various reasons like public and stake holder pressure, image building, for sustainable development, innovative leaderships, brand positioning to aid marketing, etc (Maloni,2006). They also add, along with differences of various elements in different supply chains, unique issue exist in managing CSR, making the CSR and SCM more complex. Husted and Salazar (2006) affirm that companies should 
put their social responsibility strategies into practice with the intention of improving both economic and social performance. The performance parameters of CSR includes components that are financial (as per theoretical) and non-financial (social/environmental) by empirical researches under Business Case of Sustainability (BCS) perceptive (Pedersen, 2006; Russo, 2009). The tracking, quantifying or finding the auditable facts of environment and social issues of a company are difficult. Thus predicting the financial situation that may pervade in future becomes much more uncertain and complex with employee and firm commitment as reported by Meyer et al., (2002). Along with variant range of differences CSR rhetoric and actual practices, differences in Financial Parameters (FP) measures, large variants of Environment Social Parameter (ESP) and multi-dimensional ESP has not only made the research complex but also resulted in making CSR a much debated and ambiguous construct (Pedersen, 2006). Lack of effort to test definitions, lack of significance testing, inadequate sample sizes, lack of control for interaction with other variables, factors of configuration of stake holders, degree of visibility, unique internal competencies and level of regulation have been some of the barriers of CSR implementation in industries.

A theoretical review by Filho et al. (2010) demonstrates the association between social strategy and competitive advantage that are influenced by opportunities, resources, skills, corporation merits, industry structure, and stakeholders. These days the organisations are forced to accept clean mechanisms in operations as part of stringent government policies. They have also defined CSR for sustainable society. The organisation earns a bad reputation due to lack of CSR with environmental policies as discussed by Cruz based on related articles (Fabian, 2000; Dowling, 2001; Brun, 2001; Tina, 2008). Some of the CSR shared across organisations rather than a single stage goal, where the entire chain working for common goal are cited in Harvard business review on Green promise (Oct 2010). Partner's loyalty can be studied from Toyotas long-time trusted supplier, even during crisis, working towards a common manufacturing goal. Successful Brand building through long term relationship and responsibility sharing on sustainable procurement and manufacturing can be studied from Starbucks Model. Other models of CSR on social and environmental management are studied by Filho et al. (2010), based on Abreu (2001) and Pasa (2004). A study focused on the apparel and agriculture sectors, and drawing upon consultations in China, Honduras, India, Kenya, the United States, and Europe conducted by World Bank in 2003, reveal the existence of less awareness, concern, and external pressure to address environmental matters is highlighted by Nadler (1998). But today products are facing demand from customers who insist on green labelling, ensuring sustainable manufacturing, processing, packing etc. The various stages of product development is accounted in life cycle assessment (LCA) (Vaidyanathan Jayaraman, 2007). Life Cycle Assessment (LCA) is a structured approach to define and evaluate the total environmental load associated with providing a service. Since there are various players at various stages with different functional layers of supply chain, in-order to bring boundaries for environmental holistic approach, these players must be aware and realise that the operational concern and LCA are beyond an individual entity. Need and importance of LCA throughout the SCM and in extension as back-pack (environmental impact of activities accumulated till that stage) effect of LCA analysis at each company level involved in the SCM is highlighted in the work by Winkler (Winkler, 2011a).

For a SSCM, the CSR can be linked to the environment commitment the firm opts via LCA, i.e., controlled manufacturing in environment consciousness, or any environmental risk reduction initiatives. CSR risk model have functions of both the product transactions and the levels of social responsibility activities. Cruz and Juttner suggest that supply chain-relevant risk sources fall into three categories: environmental risk (e.g., fire, social political actions (CSR), or acts of God), organizational risk (e.g., production uncertainties), and network-related risk (TinaWakolbinger, 2008), (Uta Jttner 2003). Norrman and Jansson argue that network-related risk arises from the interaction between organizations within the supply chain (e.g., due to insufficient interaction and cooperation) (Andreas Norrman Ulf Jansson, 2004). The guidelines for CSR for environment advocate (UN global Compact) the following 3 principles among 10: Principle 7: Businesses should support a precautionary approach 
to environmental challenges; Principle 8: undertake initiatives to promote greater environmental responsibility; and Principle 9: encourage the development and diffusion of environmentally friendly technology. In this paper we suggest to the need to incorporate, Corporate Social Responsibility Index (CSRI) to business practices in order to overcome the difficulties in managing and measuring the environment issues related to product flow across the chain (SC). The need for CSR is logically coined to benefit internal (employees, customers and stockholders) and external stake holders (community activists, public institutions, media, and other non-governmental organizations). The CSR necessity is argued by Perrini et al.as a device for enhancing firm's worthiness and in strengthening the relationship among the stake holders (Francesco Perrini Angeloantonio Russo, 2009).

\section{New research Directions}

Future directions may embrace (i) Research and Development for sustainability on indirect factors, (ii) formulation of strategies for sustainability implementation, (iii) awareness models to enhance greenability of chains, (iv) micro operational aspects which remain as future scope in terms of being purely green such as usage of paper (may use recycled paper, reduce plastic stationaries, use of one-side papers). Some of least researched areas in GSCM take account of inventory model and analysis, delivery process as a whole in contributing to non-green activities, responsibility fixing at the consumer end and value fixing at the reverse chain is less explicit, etc. Communication and e-waste accounting, administrative reworks follow up through documentations, etc. are not accounted in the present day work on GSCM. Economic aspects or cost analysis based on performance measures at implementation level of GSCM practices is an area to be explored. Alignment of competitive strategy with environment and strategic concerns, and development of implementation models are immediate requirement. Concurrent engineering strategies and models based on current engineering attempt as a tool for continuous improvement to environment quality can be tried. The profit and market share vary when GSCM is implemented across countries, may be due the variation in environmental policy and regulations, regional political differences, management practices and measures adopted by organisations, etc. Another dimension that could be linked with the parametric matrix model for further studies is the cost-quality dimension with reference to Sustainability. The carbon policy and pricing still experience uncertainties as a result of varying quantification methods adopted. The carbon management systems for supply chain should comprise carbon governance defined with a carbon policy and proper mechanisms for carbon emission disclosure right from supplier to customer and reverse chain. Other criteria for carbon management may involve carbon risk assessment, carbon reduction targets, training and awareness on carbon management, etc. The implementation dimension can initiate carbon emission mitigation steps, carbon management information systems, carbon trading with accounting for carbon inventory, mandatory carbon emission verification and reporting. Further, CSR can be given a grading by virtue of the reduction / initiative taken towards decarbonisation by the SC. The scope for emission reduction under single chain management for particular product in a region is worth exploring and cost benefit analysis worth can also be studied.

\section{Conclusion}

It is observed that the improvement of ecology can be materialised only by hand-in-hand cooperation of top management and operational team. The four drivers needed are desire to cut energy costs, concern about environmental regulation, realising customer preference to green products, knowledge to boost productivity with reduced emission. GSCM being intricate and complex, continuous effort for creating awareness, reminders and interactions among the players are desired for generating green values across the chain. The parametric matrix along with such referencing will be a value addition to the best of our knowledge in the plethora of GSCM resources. The analysis stage of a SCM includes identification, quantification, evaluation, and prioritisation of environ-mental harm based on this matrix. The main highlight of this effort is that various organisations exist with different combination of levels and stages of SCM in their way to GSCM. In framing the parameter matrix a close working link of strategic and tactical activities are considered unlike other works that leave a gap between top 
management and daily operations. To be an organisation completely dedicated to GSCM this framework will form the basis to further improvements towards ecological concerns. This framework will enable industries to adhere to the triple point sustainability through CSR initiatives in the long run. Main advantage of such a matrix is that, from whichever cell the organisation currently exists the path to convergence to the common goal of eco-friendliness is easily identified. This will ensure industries to operate with strategic alignment to CSR to achieve best competitive alignment and financial returns. Another main advantage of such a metric is building green value stage by stage towards a holistic chain by highlighting the bottleneck with ease on analysis. Even if an industry wants to build value at grass root level with this metric as a benchmark, one can easily develop a framework for sustainability, as it is a long term goal to be realised in a futuristic manner. The green watch group like WEEE, UNCCP, GreenPeace, carbon disclosure projects, etc. will be thus able to help green adoption in SCM through such a micro-model. This micro model detailing can be used to calculate, monitor, and track the carbon emissions associated with any operational activity within and among the trade partners of any industry.

\section{References}

Abdallah, T., Diabat, A., \& Simchi-Levi, D. (2012). Sustainable supply chain design: a closed-loop formulation and sensitivity analysis. Production Planning \& Control, 23(2-3), 120-133.

Ahi, P., \& Searcy, C. (2013). A comparative literature analysis of definitions for green and sustainable supply chain management. Journal of Cleaner Production, 52, 329-341.

Akçali, E., \& Bayindir, Z. P. (2008). Analyzing the effects of inventory cost setting rules in a disassembly and recovery environment. International Journal of Production Research, 46(1), 267 288. http://doi.org/10.1080/00207540600710962

Alshamrani, A., Mathur, K., \& Ballou, R. H. (2007). Reverse logistics: simultaneous design of delivery routes and returns strategies. Computers \& Operations Research, 34(2), 595-619. http://doi.org/10.1016/j.cor.2005.03.015

Altekin, F. T., Kandiller, L., \& Ozdemirel, N. E. (2008). Profit-oriented disassembly-line balancing. International Journal of Production Research, 46(10), 2675-2693. http://doi.org/10.1080/00207540601137207

Amar Ramudhin, A. C., \& Paquet, M. (2009). On the Design of Sustainable, Green Supply Chains. IEEE, 978-984.

Anderson L. M., \& Bateman, T. S. (2000). Individual environmental initiative: Championing natural environmental issues in US business organizations. Academy of Management Journal, 43 (4), 548 570.

Angell L. C., \& Klassen, R. D. (1999). Integrating environmental issues into the mainstream: an agenda for research in operations management. Journal of Operations Management, 17, 575-598.

Anil S Dube and R.R.Gawande. (2012). A Review On Green Supply Chain Management. In IJCA Proceedings on International Conference in Computational Intelligence ICCIA(10). Retrieved from http://www.ijcaonline.org/proceedings/iccia/number10/5162-1074

Ans Kolk, R. T. (2002). The Effectiveness of Self- regulation: Corporate Codes of Conduct and Child Labour. European Management Journal, 20, 260-271.

Apratul Chandra Shukla, S. G. D. (2009). Environmentally responsive supplychains Learnings from the Indian autosector. Journal of Advances in Management Research Emerald Group Publishing Limited, 6(2).154-171.

Aras, N., \& Aksen, D. (2008). Locating collection centers for distance- and incentive-dependent returns. International Journal of Production Economics, 111(2), 316-333. http://doi.org/10.1016/j.ijpe.2007.01.015

Aronsson, H., \& Huge Brodin, M. (2006). The environmental impact of changing logistics structures. The international journal of logistics management, 17(3), 394-415.

Azzone, G., \& Noci, G. (1998). Seeing ecology and "green" innovations as a source of change. Journal of Organizational Change Management, 11(2), 94-111.

Baker, W. E., \& Sinkula, J. M. (2005). Environmental Marketing Strategy and Firm Performance: 
Effects on New Product Performance and Market Share. Journal of the Academy of Marketing Science, 33(4), 461-475. http://doi.org/10.1177/0092070305276119

Banerjee, S. B. (1998). Corporate Environmentalism: Perspectives from Organizational Learning. Management Learning, 29, 147-164.

Bansal, \& Roth. (2000). Why Companies Go Green: A Model of Ecological Responsiveness. Academy of Management Journal, 43, 717-736.

Bansal, P., \& Hunter, T. (2003). Strategic explanations for the early adoption of ISO 14001. Journal of Business Ethics, 46(3), 289-299.

Banerjee, S. B., Iyer, E. S., \& Kashyap, R. K. (2003). Corporate environmentalism: antecedents and influence of industry type. Journal of Marketing, 67(2), 106-122.

Beamon, B. M. (1999). Designing the green supply chain. Logistics information management, 12(4), 332-342.

Benjaafar, S., Li, Y., \& Daskin, M. (2013). Carbon footprint and the management of supply chains: Insights from simple models. Automation Science and Engineering, IEEE Transactions on, 10(1), 99-116.

Bevilacqua, M., Ciarapica, F. E., \& Giacchetta, G. (2007). Development of a sustainable product lifecycle in manufacturing firms: a case study. International Journal of Production Research, 45(1819), 4073-4098. http://doi.org/doi:10.1080/00207540701439941

Bin, Y., \& Jun, H. (2009, July). An analysis on green supply chain management in E-Commerce under the economic globalization. In Business Intelligence and Financial Engineering, 2009. BIFE'09. International Conference on (pp. 595-599). IEEE.

Bloemh of-Ruwaard, J. M., Van Beek, P., Hordijk, L., \& Van Wassenhove, L. N. (1995). Interactions between operational research and environmental management. European journal of operational research, 85(2), 229-243.

Bojarski, A. D., Laínez, J. M., Espuña, A., \& Puigjaner, L. (2009). Incorporating environmental impacts and regulations in a holistic supply chains modeling: An LCA approach. Computers \& Chemical Engineering, 33(10), 1747-1759.

Bonney, M., \& Jaber, M. Y. (2011). Environmentally responsible inventory models: Non-classical models for a non-classical era. International Journal of Production Economics, 133(1), 43-53. Retrieved from http://ideas.repec.org/a/eee/proeco/v133y2011i1p43-53.html

Boström, M., \& Klintman, M. (2008). Eco-standards, product labelling and green consumerism. Basingstoke: Palgrave Macmillan.

Bovea, \& Wang. (2003). Identifying environmental improvement options by combining life cycle assessment and fuzzy set theory. International Journal of Production Research, 41, 593-609.

Bovea, M., \& Pérez-Belis, V. (2012). A taxonomy of ecodesign tools for integrating environmental requirements into the product design process.Journal of Cleaner Production, 20(1), 61-71.

Bowen, F. E., Cousins, P. D., Lamming, R. C., \& Farukt, A. C. (2001). The role of supply management capabilities in green supply. Production and operations management, 10(2), 174-189.

Bras, B., \& McIntosh, M. W. (1999). Product, process, and organizational design for remanufacture an overview of research. Robotics and Computer-Integrated Manufacturing, 15(3), 167-178. http://doi.org/10.1016/S0736-5845(99)00021-6

Brennan, L., Gupta, S. M., \& Taleb, K. N. (1994). Operations planning issues in an assembly/disassembly environment. International Journal of Operations \& Production Management, 14(9), 57-67.

Buysse, K., \& Verbeke, A. (2003). Proactive environmental strategies: a stakeholder management perspective. Strategic management journal, 24(5), 453-470.

Carter, C. R., \& Carter, J. R. (1998). Inter-organizational Determinants of Environmental Purchasing: Initial Evidence from the Consumer Products Industries*. Decision Sciences, 29(3), 659-684.

Carter, C. R., \& Rogers, D. S. (2008). A framework of sustainable supply chain management: moving toward new theory. International journal of physical distribution \& logistics management, 38(5), 360-387.

Chambers, E., Chapple, W., Moon, J., \& Sullivan, M. (2003). CSR in Asia: A seven country study of 
CSR website reporting.

Chandler, S. G. (2001). Defining Corporate Social Responsibility,. Ethical Performance Best Practice.

Chang \& Fong, (2010). Green Product Quality. Green corporate image, Green customer satisfaction, and Green Custmer Loyalty.

Charlette A. Geffen, S. R. (2000). Suppliers and environmental innovation: The automotive paint process. International Journal of Operations \& Production Management, 20, 166-186.

Chien, M. K., \& Shih, L. H. (2007). An empirical study of the implementation of green supply chain management practices in the electrical and electronic industry and their relation to organizational performances.

Choi, Y., \& Zhang, N. (2011). Does proactive green logistics management improve business performance? A case of Chinese logistics enterprises. African Journal of Business Management, 5(17), 7564-7574.

Chiou, T. Y., Chan, H. K., Lettice, F., \& Chung, S. H. (2011). The influence of greening the suppliers and green innovation on environmental performance and competitive advantage in Taiwan. Transportation Research Part E: Logistics and Transportation Review, 47(6), 822-836.

Clemens, B., Bamford, C. E., \& Douglas, T. J. (2008). Choosing strategic responses to address emerging environmental regulations: size, perceived influence and uncertainty. Business Strategy and the Environment, 17(8), 493-511. http://doi.org/10.1002/bse.601

Clift, R., \& Wright, L. (2000). Relationships Between Environmental Impacts and Added Value Along the Supply Chain. Technological Forecasting and Social Change, 65, 281-295.

Christopher, M., \& Peck, H. (2004). Building the resilient supply chain. The international journal of logistics management, 15(2), 1-14.

Clifford Defee, C., Esper, T., \& Mollenkopf, D. (2009). Leveraging closed-loop orientation and leadership for environmental sustainability. Supply Chain Management: An International Journal, 14(2), 87-98.

Coleman, L. (2006). Frequency of man-made disasters in the 20th century.Journal of Contingencies and Crisis Management, 14(1), 3-11. http://onlinelibrary.wiley.com/doi/10.1111/j.1468-.

Cordano, M., \& Frieze, I. H. (2000). Pollution reduction preferences of US environmental managers: Applying Ajzen's theory of planned behavior.Academy of Management journal, 43(4), 627-641.

Cristofari, M., Deshmukh, A., Wang, B., (1996). Green quality function deployment. In: Environmentally,. Proceedings of the Fourth International Conference on Conscious Design and Manufacturing, Cleveland, Ohio, July, 297-304.

Cruz, J. M., \& Wakolbinger, T. (2008). Multiperiod effects of corporate social responsibility on supply chain networks, transaction costs, emissions, and risk. International Journal of Production Economics, 116(1), 61-74.

D .W. Burt, D. S. S. (2003). World Class Supply Management: The key to Supply Chain Management (7ed.). Tata McGraw-Hill.

Burt, D. N., Pinkerton, R. L., \& Pinkerton, R. D. (1996). A purchasing manager's guide to strategic proactive procurement. Tang Kinh Cacment.

Davis-Walling, P., \& Batterman, S. A. (1997). Environmental reporting by the Fortune 50 firms. Environmental Management, 21(6), 865-875.

Dayna Simpson, D. P., \& Samson, D. (2007). Greening the Automotive Supply Chain: A Relationship Perspective. InternationalJournalofOperations\& ProductionManagement 27,28-48 Q EmeraldGroupPublishingLimited 0144-3577 DOI10.1108/01443570710714529, 27, pp.28-48.

Debets, F. J., \& Van Wassenhove, L. (1992). A guided tour through applications of OR-techniques to environmental problems. INSEAD.

De Ruyter, K., De Jong, A., \& Wetzels, M. (2009). Antecedents and consequences of environmental stewardship in boundary-spanning B2B teams. Journal of the Academy of Marketing Science, 37(4), 470-487.

Delfmann W., A. S. \& G. M. (2002). The impact of electronic commerce on logistics service providers. International Journal of Physical Distribution \& Logistics Management, 32(3), 203-222.

Diabat, A., \& Simchi-Levi, D. (2009, December). A carbon-capped supply chain network problem. 
In Industrial Engineering and Engineering Management, 2009. IEEM 2009. IEEE International Conference on (pp. 523-527). IEEE.

Diane Holt, A. G. (2009). An empirical study of green supply chain management practices amongst UK manufacturers Journal of Manufacturing Technology Management, Vol. 20 Iss: 7, pp.933 - 956. Journal of Manufacturing Technology Management, 20,933 - 956.

Dobos, I., \& Richter, K. (2006). A production/recycling model with quality consideration. International Journal of Production Economics, 104(2), 571-579. http://doi.org/10.1016/j.ijpe.2005.09.006

Drumwright, M. E. (1994). Socially Responsible Organizational Buying: Environmental Concern as a Noneconomic Buying Criterion. Journal of Marketing, 58, 1-19.

Dunlap, R. E., \& Van Liere, K. D. (1978). The "new environmental paradigm".The journal of environmental education, 9(4), 10-19.

Eisenhardt, K. M., \& Martin, J. A. (2000). Dynamic capabilities: what are they?. Strategic management journal, 21(10-11), 1105-1121.

Ellram, L. M., \& Cooper, M. C. (1993). The relationship between supply chain management and Keiretsu. The International Journal of Logistics Management, 4(1), 1-12.

Emmelhainz, M. A., \& Adams, R. J. (1999). The apparel industry response to "sweatshop" concerns: A review and analysis of codes of conduct. Journal of Supply Chain Management, 35(2), 51-57.

Erol, I., Nurtanis Velioglu, M., Sivrikaya Serifoglu, F., Büyüközkan, G., Aras, N., Demircan Çakar, N., \& Korugan, A. (2010). Exploring reverse supply chain management practices in Turkey. Supply Chain Management: An International Journal, 15(1), 43-54

Evangelista P. Huge - Brodin M., I. (2011). The impact of 3PL's green initiatives on the purchasing of transport and logistics services: an exploratory study. Proceedings of the 20th Annual IPS ERA Conference Vision 20/20 - Preparing Today for Tomorrow's Challenges, Maastricht, the Netherlands.

Fiksel, J., \& Fiksel, J. R. (1996). Design for environment: creating eco-efficient products and processes. McGraw-Hill. Retrieved from http://books.google.co.in/books?id=_upTAAAAMAAJ

Feldman, S. J., Soyka, P. A., \& Ameer, P. G. (1997). Does improving a firm's environmental management system and environmental performance result in a higher stock price?. The Journal of Investing, 6(4), 87-97.

Ferguson, N., \& Browne, J. (2001). Issues in end-of-life product recovery and reverse logistics. Production Planning \& Control, 12(5), 534-547.

Fineman, S., \& Clarke, K. (1996). Green Stakeholders: Industry Interpretations and Response. Journal of Management studies, 33(6), 715-730.

Fleischmann, M., Krikke, H. R., Dekker, R., \& Flapper, S. D. P. (2000). A characterisation of logistics networks for product recovery. Omega, 28(6), 653-666.

Florida, R. (1996). Lean and Green: The Move To Environmentally Consciousous Manufacturing. California Management Review, 39 (1), 80-105.

Florida, R., \& Davison, D. (2001). Gaining from green management. California Management Review, 43(3), 63-84.

Perrini, F., Russo, A., Tencati, A., \& Vurro, C. (2009). Going beyond a long-lasting debate: What is behind the relationship between corporate social and financial performance. Bocconi University, Milano, IT. Working paper

Giuntini R., G. (2003). Remanufacturing: The next great opportunity for boosting US productivity. Business Horizons, 41-48.

González-Benito, J., \& González-Benito, Ó. (2006). The role of stakeholder pressure and managerial values in the implementation of environmental logistics practices. International Journal of Production Research, 44(7), 1353-1373.

Grabowski, M., \& Roberts, K. (1997). Risk mitigation in large-scale systems: Lessons from high reliability organizations. California Management Review,39(4), 152.

Guide, V. D. R. (2000). Production planning and control for remanufacturing: Industry practice and research needs. Journal of Operations Management, 18(4), 467-483. http://doi.org/10.1016/S02726963(00)00034-6 
Guide Jr, V. D. R., Jayaraman, V., Srivastava, R., \& Benton, W. C. (2000). Supply-chain management for recoverable manufacturing systems. Interfaces, 30(3), 125-142.

Guide, V. D. R., \& Wassenhove, L. N. (2001). Managing product returns for remanufacturing. Production and Operations Management, 10(2), 142-155.

Gungor, A., \& Gupta, S. M. (1999). Issues in environmentally conscious manufacturing and product recovery: A survey. Computers and Industrial Engineering, 36(4), 811-853. http://doi.org/10.1016/S0360-8352(99)00167-9.

Gupta, S. M., \& Veerakamolmal, P. (2000). A bi-directional supply chain optimization model for reverse logistics.

Gupta, K. M., \& Gunasekaran, A. (2005). Costing in new enterprise environment: A challenge for managerial accounting researchers and practitioners. Managerial Auditing Journal, 20 (4), 337-353.

Hall, J. (2000). Environmental supply chain dynamics. Journal of cleaner production, 8(6), 455-471.

Hall, J. (2001). Environmenttal Supply Chain Innovation. Greener Management International, 200(35), 105-119.

Hall, J., \& HarrieVredenburg. (2005)., "Managing Stakeholder Ambiguity,." Sloan Management Review, 47, 11-13.

Halldórsson, Á., Kotzab, H., \& Skjøtt-Larsen, T. (2009). Supply chain management on the crossroad to sustainability: a blessing or a curse?.Logistics Research, 1(2), 83-94.

Handfield, R., Walton, S. V, Sroufe, R., \& Melnyk, S. A. (2002). Applying environmental criteria to supplier assessment: A study in the application of the Analytical Hierarchy Process. European Journal of Operational Research, 141(1), 70-87. http://doi.org/10.1016/S0377-2217(01)00261-2

Harland, C., Brenchley, R., \& Walker, H. (2003). Risk in supply networks. Journal of Purchasing and Supply Management, 9(2), 51-62. http://doi.org/10.1016/S1478-4092(03)00004-9

Hassini, E., Surti, C., \& Searcy, C. (2012a). A literature review and a case study of sustainable supply chains with a focus on metrics. International Journal of Production Economics, 140(1), 69-82. http://doi.org/10.1016/j.ijpe.2012.01.042

Hassini, E., Surti, C., \& Searcy, C. (2012b). A literature review and a case study of sustainable supply chains with a focus on metrics. International Journal of Production Economics, 140(1), 69-82. http://doi.org/10.1016/j.ijpe.2012.01.042

Heizer, J. H., Render, B., \& Weiss, H. J. (2004). Operations management (Vol. 8). Pearson Prentice Hall.

Hendricks, K. B., \& Singhal, V. R. (2005). Association between supply chain glitches and operating performance. Management science, 51(5), 695-711.

Hervani, A. A., Helms, M. M., \& Sarkis, J. (2005). Performance measurement for green supply chain management. Benchmarking: $\quad$ An international journal, 12(4), 330-353. http://doi.org/10.1108/14635770510609015

Hong C. Zhang Tsai C. Kuo, \& Huitian Lu Samuel H. Huang. (1997). Environmentally Conscious Design and Manufacturing: A State-of-the-Art Survey. Journal of Manufacturing Systems, 16, 352371.

Hua, G., Cheng, T. C. E., \& Wang, S. (2011). Managing carbon footprints in inventory management. International Journal of Production Economics, 132(2), 178-185. http://doi.org/10.1016/j.ijpe.2011.03.024

Huang, Y. Y., \& Li, S. J. (2010). How to achieve agility: A case study of a personal computer original equipment manufacturer in Taiwan. Journal of Manufacturing Systems, 29(2-3), 63-70. http://doi.org/10.1016/j.jmsy.2010.09.001

Hugo, A., Pistikopoulos, E.N. (2005). Environmentally conscious long-range planning and design of supply chain networks. Journal of Cleaner Production, 13(1). 1471-1491

Husted, B. W., \& De Jesus Salazar, J. (2006). Taking Friedman Seriously: Maximizing Profits and Social Performance*. Journal of Management Studies, 43(1), 75-91. http://doi.org/10.1111/j.14676486.2006.00583.x

Hsu, C. W., \& Hu, A. H. (2008). Green supply chain management in the electronic industry. International Journal of Environmental Science \& Technology, 5(2), 205-216. 
Ilgin, M. A., \& Gupta, S. M. (2010). Environmentally conscious manufacturing and product recovery (ECMPRO): A review of the state of the art. Journal of Environmental Management, 91(3), 563591. http://doi.org/10.1016/j.jenvman.2009.09.037

Harris, I., Naim, M., Palmer, A., Potter, A., \& Mumford, C. (2011). Assessing the impact of cost optimization based on infrastructure modelling on $\mathrm{CO} 2$ emissions. International Journal of Production Economics, 131(1), 313-321.

Henriques, I., \& Sadorsky, P. (2007). Environmental management systems and practices: an international perspective. Environmental Policy and Corporate Behaviour, 34.

Joong-Kun Cho, J., Ozment, J., \& Sink, H. (2008). Logistics capability, logistics outsourcing and firm performance in an e-commerce market. International Journal of Physical Distribution \& Logistics Management, 38(5), 336-359.

Jayaraman, V. (2006). Production planning for closed-loop supply chains with product recovery and reuse: an analytical approach. International Journal of Production Research, 44(5), 981-998.

Jean-Paul, R., Slack, B., \& Comtois, C. (2001). Green Logistics [M]. Published in AM Brewer, KJ Button and DA Hensher (eds.). The Handbook of Logistics and Supply-Chain Management [M].

Johansson, G. (2002). Success factors for integration of ecodesign in product development: a review of state of the art. Environmental Management and Health, 13(1), 98-107.

Joseph Sarkisa James J Cordeiro. (2001). An empirical evaluation of environmental efficiencies and firm performance: Pollution prevention versus end-of-pipe practice. European Journal of Operational Research, 135, 102-113.

Jumadi, H., \& Zailani, S. (2010). Integrating Green Innovations in Logistics Services Towards Logistics Services Sustainability: A Conceptual Paper. Environmental Research Journal, 4, 261271.

Junquera, B., \& del Bro, J. (2012). Research Effort, Functional Integration, and Environmental ActionBased Competitive Advantage: An Empirical Study. Int. J. Environ. Res., 6(3), 585-596.

Kainuma, Y., \& Tawara, N. (2006). A multiple attribute utility theory approach to lean and green supply chain management. International Journal of Production Economics, 101(1), 99-108.

Karakayali, I., Emir-Farinas, H., \& Akcali, E. (2007). An analysis of decentralized collection and processing of end-of-life products. Journal of Operations Management, 25(6), 1161-1183. http://doi.org/10.1016/j.jom.2007.01.017

Kaya, O. (2010). Incentive and production decisions for remanufacturing operations. European Journal of Operational Research, 201(2), 442-453. http://doi.org/10.1016/j.ejor.2009.03.007

Keating, M. (1993). Earth Summit's agenda for change: a plain language version of Agenda 21 and the other Rio Agreements. In Earth Summit's agenda for change: a plain language version of Agenda 21 and the other Rio Agreements. Centre for Our Common Future.

Kilbourne, W. E., \& Beckmann S.C., 1998a. Review and critical assessment of research on marketing and the environment. Journal of Marketing Management 14 (6), 513-32. Klassen, R. D., \& Whybark, D. C. (1999). The impact of environmental technologies on manufacturing performance. Academy of Management journal,42(6), 599-615.

Klausner, M., \& Hendrickson, C. T. (2000). Reverse-logistics strategy for product takeback. Interfaces, 30(3), 156-165.

Koh, S. C. L., Gunasekaran, A., \& Tseng, C. S. (2012). Cross-tier ripple and indirect effects of directives WEEE and RoHS on greening a supply chain.International Journal of Production Economics, 140(1), 305-317.

Kohn, C., \& Brodin, M. H. (2008). Centralised distribution systems and the environment: how increased transport work can decrease the environmental impact of logistics. International Journal of Logistics: Research and Applications, 11(3), 229-245.

Kolk, A., \& Van Tulder, R. (2002). The Effectiveness of Self-regulation:: Corporate Codes of Conduct and Child Labour. European Management Journal, 20(3), 260-271.

Koplin, J., Seuring, S., \& Mesterharm, M. (2007). Incorporating sustainability into supply management in the automotive industry-the case of the Volkswagen AG. Journal of Cleaner Production, 15(11), 1053-1062. 
Kriwet, A. Zussman, E., G. S. (1995). Systematic integration of design-for-recycling into product design. International Journal of Production Economics, 38(1): 15.

Kroll, E., \& Hanft, T. A. (1998). Quantitative evaluation of product disassembly for recycling. Research in engineering design, 10(1), 1-14.

Kumar, S., Teichman, S., \& Timpernagel, T. (2012). A green supply chain is a requirement for profitability. International Journal of Production Research,50(5), 1278-1296.

Kuo, T. C. (2000). .Disassemblysequenceandcostanalysisforelectromechanical products. Robotics and Computer Integrated Manufacturing, 16, 43-54.

Lambert, S., Riopel, D., \& Abdul-Kader, W. (2011). A reverse logistics decisions conceptual framework. Computers and Industrial Engineering, 61(3), 561-581. http://doi.org/10.1016/j.cie.2011.04.012

Lamming, R., \& Hampson, J. (1996). The environment as a supply chain management issue. British Journal Management, 7(Special, S45-S62.

Lee, J. J., O'Callaghan, P., \& Allen, D. (1995). Critical review of life cycle analysis and assessment techniques and their application to commercial activities. Resources, conservation and recycling, 13(1), 37-56.

Lee, S. Y. (2008). Drivers for the participation of small and medium-sized suppliers in green supply chain initiatives. Supply Chain Management: An International Journal, 13(3), 185-198.

Li, Y. (2011). Research on the Performance Meas urement of Green Supply Chain Management in China. Journal of Sustainable Developm, 4(3), 101-107.

Lieb, K. J., \& Lieb, R. C. (2010). Environmental sustainability in the third-party logistics (3PL) industry. International Journal of Physical Distribution \& Logistics Management, 40(7), 524-533.

Lieckens, K., \& Vandaele, N. (2012). Multi-level reverse logistics network design under uncertainty. International Journal of Production Research, 50(1), 23-40.

Lin C.Y. Ho, Y. H. (2008). An empirical study on logistics service providers intention to adopt green innovations,. Journal of Technology Management \& Innovation, 3(1), 17-26.

Lin, R.-J. (2012). Moderating effects of total quality environmental management on environmental performance. African Journal of Business Management, 5(20), 8088-8099.

Lin, Z., Zhao, X., Ismail, K. M., \& Carley, K. M. (2006). Organizational design and restructuring in response to crises: Lessons from computational modeling and real-world cases. Organization Science, 17(5), 598-618.

Linton, J. D., Klassen, R., \& Jayaraman, V. (2007). Sustainable supply chains: An introduction. Journal of Operations Management, 25(6), 1075-1082.

Mckinnon Browne, W. (2011). Book - Green Logistics: Improving the Environmental Sustainability of Logistics.

Meade, L., \& Sarkis, J. (2002). A conceptual model for selecting and evaluating third-party reverse logistics providers. Supply Chain Management: An International Journal, 7(5), 283-295.

Meerkamm, H. (1994). Design for X-A core area of design methodology. Journal of Engineering Design, 5(2), 165-181.

Mehta, C., \& Wang, B. (2001). Green quality function deployment III: a methodology for developing environmentally conscious products. Journal of design and manufacturing automation, 1(1-2), 116.

Melnyk, S. A., Sroufe, R. P., \& Calantone, R. (2003). Assessing the impact of environmental management systems on corporate and environmental performance. Journal of Operations Management, 21(3), 329-351.

Meyer, J. P., Stanley, D. J., Herscovitch, L., \& Topolnytsky, L. (2002). Affective, continuance, and normative commitment to the organization: A meta-analysis of antecedents, correlates, and consequences. Journal of vocational behavior, 61(1), 20-52.

Maloni, M. J., \& Brown, M. E. (2006). Corporate social responsibility in the supply chain: an application in the food industry. Journal of business ethics,68(1), 35-52.. http://doi.org/DOI 10.1007A10551-006-9038-0

Min, H., \& Galle, W. P. (1997). Green purchasing strategies: trends and implications. International 
Journal of Purchasing and Materials Management,33(2), 10-17.

Miles, M. P., Munilla, L. S., \& Russell, G. R. (1997). Marketing and environmental registration/certification: what industrial marketers should understand about ISO 14000. Industrial Marketing Management, 26(4), 363-370.

Minton, A. P., \& Rose, R. L. (1997). The effects of environmental concern on environmentally friendly consumer behavior: An exploratory study. Journal of Business Research, 40(1), 37-48.

Moyer, L. K., \& Gupta, S. M. (1997). Environmental concerns and recycling/disassembly efforts in the electronics industry. Journal of Electronics Manufacturing, 7(01), 1-22.

Murphy, P. R., Poist, R. F., \& Braunschwieg, C. D. (1994). Management of environmental issues in logistics: Current status and future potential.Transportation journal, 48-56.

Murphy, P. R., Poist, R. F., \& Braunschweig, C. D. (1995). Role and relevance of logistics to corporate environmentalism: an empirical assessment. International Journal of Physical Distribution \& Logistics Management, 25(2), 5-19.

Murphy, P. R., \& Poist, R. F. (2003). Green perspectives and practices: a "comparative logistics" study. Supply chain management: an international journal, 8(2), 122-131.

Mutingi, M. (2013). Developing green supply chain management strategies: A taxonomic approach. Journal of Industrial Engineering and Management,6(2), 525-546.

Nadler, S. (1998). The Green Stairway: Surviving and Flourishing in EnvironmentalManagement,. Corporate Environmental Strategy, 5(2), 14-21.

Nidhi, M. B., \& Pillai, V. M. (2011). Development of Green Supply Chain Transformation Matrix from Environment Management System. Proceedings of the National Conference on Emerging Trends in Industrial Engineering and Management (ETRIM2011),68 - 73, NIT Calicut, Kerala

Norrman, A., \& Jansson, U. (2004). Ericsson's proactive supply chain risk management approach after a serious sub-supplier accident. International journal of physical distribution \& logistics management, 34(5), 434-456.

Oral, M. (2009). Green Supply Chain Management Research: Ontological and Epistemological Issues (pp. 1-12). CIRRELT.

Papadopoulos, A. M., \& Giama, E. (2007). Environmental performance evaluation of thermal insulation materials and its impact on the building. Building and environment, 42(5), 2178-2187.

Paillé, P., Boiral, O., \& Chen, Y. (2013). Linking environmental management practices and organizational citizenship behaviour for the environment: a social exchange perspective. The International Journal of Human Resource Management, 24(18), 3552-3575.

Pedersen, E. R. (2006). Making Corporate Social Responsibility (CSR) Operable: How Companies Translate Stakeholder Dialogue into Practice. Business and Society Review 111(2), 137-163.

Pirages, D. C., \& Ehrlich, P. R. (1974). Ark II; social response to environmental imperatives [by] Dennis C. Pirages [and] Paul R. Ehrlich.

Porter, M. E., \& van der Linde, C. (1995a). Green and Competitive: Ending the Stalemate. Harvard Business Review, 120-133.

Porter, M. E., \& van der Linde, C. (1995b). Toward a New Conception of the EnvironmentCompetitiveness Relationship. Journal of Economic Perspectives, 9, 97-118.

Qiu, Z., Prato, T., \& McCamley, F. (2001). Evaluating environmental risks using safety-first constraints. American Journal of Agricultural Economics,83(2), 402-413.

Quinn, B., (1999). E-System manages inventory to reduce risk. Pollution Engineering 31, 27-28.

Ramudhin, A., Chaabane, A., Kharoune, M., \& Paquet, M. (2008). Carbon Market Sensitive Green Supply Chain Network Design. In Industrial Engineering and Engineering Management, 2008. IEEM 2008. IEEE International Conference on (1093-1097). http://doi.org/10.1109/IEEM.2008.4738039

Ramus, C. A. (2001). Organizational Support for Employees: Encouraging Creative Ideas for Environmental Sustainability,. CaliforniaManagementReview, 43(3), 85-105.

Rao, P., \& Holt, D. (2005). Do green supply chains lead to competitiveness and economic performance?. International Journal of Operations \& Production Management, 25(9), 898-916. 
Rocky Newman, W., \& Hanna, M. D. (1996). An empirical exploration of the relationship between manufacturing strategy and environmental management: two complementary models. International Journal of Operations \& Production Management, 16(4), 69-87.

Rogers, D. S., \& Tibben-Lembke, R. (2001). An examination of reverse logistics practices. Journal of business logistics, 22(2), 129-148.

Rondinelli, D., \& Berry, M. (2000). Multimodal transportation, logistics, and the environment: managing interactions in a global economy. European Management Journal, 18(4), 398-410. http://doi.org/http://dx.doi.org/10.1016/S0263-2373(00)00029-3.

Rosen, C. M. (2001). Environmental strategy and competitive advantage: an introduction. California Management Review, 43(3), 8.

Rothenberg, S., \& Zyglidopoulos, S. C. (2007). Determinants of environmental innovation adoption in the printing industry: the importance of task environment. Business Strategy and the Environment, 16(1): 39-49. Business Strategy and the Environment, 16(1):, 39-49.

Russo, M. V. (2007). Explaining the Impact of ISO 14001 on Emission Performance: a Dynamic Capabilities Perspective on Process and Learning. Business Strategy and the Environmen Bus. Strat. Env. (in Press).

Sakao, T. (2009). Quality engineering for early stage of environmentally conscious design. The TQM Journal, 21(2), 182 - 193.

Salam, M. A. (2008). An empirical investigation of the determinants of adoption of green procurement for successful green supply chain management. In Management of Innovation and Technology, 2008. ICMIT 2008. 4th IEEE International Conference on (1038-1043).

Salzmann, O., Ionescu-Somers, A., \& Steger, U. (2005). The business case for corporate sustainability:: literature review and research options. European Management Journal, 23(1), 27-36.

Sarkis, J. (2003). A strategic decision framework for green supply chain management. Journal of cleaner production, 11(4), 397-409.

Sarkis J., M. L. M. \&Talluri S. (2004). (2004). E-logistics and the natural environment. Chain Management: An International Journal, 9(4), 303-312.

Sbihi, A., \& Eglese, R. W. (2007). Combinatorial optimization and green logistics. 4OR, 5(2), 99-116.

Seman, N. A. A., Zakuan, N., Jusoh, A., \& Arif, M. S. M. (2012). Green supply chain management: A review and research direction. International Journal of Managing Value and Supply Chains, 3(1), $1-18$.

Seuring, S., Sarkis, J., Müller, M., \& Rao, P. (2008). Sustainability and supply chain management-an introduction to the special issue. Journal of Cleaner Production, 16(15), 1545-1551.

Seuring, S., \& Muller, M. (2008). From a literature review to a conceptual framework for sustainable supply chain management. Journal of Cleaner Production, 16(15), 1699-1710. http://doi.org/10.1016/j.jclepro.2008.04.020

Seuring, S. (2013). A review of modeling approaches for sustainable supply chain management. Decision Support Systems, 54(4), 1513-1520. http://doi.org/10.1016/j.dss.2012.05.053

Sharma, S. (2000). Managerial interpretations and Organisational context as predictors of Firm choice of Environmental Strategies. Academy of Management Journal, 43, 681-97.

Sharma, S., \& Vredenburg, H. (1998). Proactive corporate environmental strategy and the development of competitively valuable organizational capabilities. Strategic management journal, 19(8), 729753.

Sheu, J. B., Chou, Y. H., \& Hu, C. C. (2005). An integrated logistics operational model for greensupply chain management. Transportation Research Part E: Logistics and Transportation Review, 41(4), 287-313. http://doi.org/10.1016/j.tre.2004.07.001

Shukla, A. C., Deshmukh, S. G., \& Kanda, A. (2010). Flexibility and Sustainability of supply chains: Are they together?. Global Journal of Flexible Systems Management, 11(1/2), 25.

Skjoett-Larsen, T. (2000). European logistics beyond 2000. International Journal of Physical Distribution and Logistics Management, 30(5), 377-387.

Simpson, D. F., \& Power, D. J. (2005). Use the supply relationship to develop lean and green 
suppliers. Supply chain management: An international Journal, 10(1), 60-68.

Sousa Filho, J. M. D., Wanderley, L. S. O., Gómez, C. P., \& Farache, F. (2010). Strategic corporate social responsibility management for competitive advantage. BAR-Brazilian Administration Review, 7(3), 294-309

Srivastava, S. K. (2007). Green supply-chain management: a state-of-the-art literature review. International journal of management reviews, 9(1), 53-80.

Staikos, T., \& Rahimifard, S. (2007). An end-of-life decision support tool for product recovery considerations in the footwear industry. International Journal of Computer Integrated Manufacturing, 20(6), 602-615.

Svensson, G. (2000). A conceptual framework for the analysis of vulnerability in supply chains,. International Journal of Physical Distribution \& Logistics Management, 30 (9), 731-749.

Szymankiewicz, J. (1993). Going green: The logistics dilemma. Logistics Information Management, 6(3), 36-43.

Srivastava, S. K., \& Srivastava, R. K. (2006). Managing product returns for reverse logistics. International Journal of Physical Distribution \& Logistics Management, 36(7), 524-546.

Tang, C. S. (2006). Perspectives in supply chain risk management. International Journal of Production Economics, 103(2), 451-488.

Thierry, M., Salomon, M., Van Nunen, J., \& Van Wassenhove, L. (1995). Strategic issues in product recovery management. California management review, 37(2), 114-135.

Tibben-Lembke, R. S., \& Rogers, D. S. (2002). Differences between forward and reverse logistics in a retail environment. Supply Chain Management: An International Journal, 7(5), 271-282.

Tseng, M.-L., Chiu, (Anthony) Shun Fung, Tan, R. R., \& Siriban-Manalang, A. B. (2013). Sustainable consumption and production for Asia: sustainability through green design and practice. Journal of Cleaner Production, 40, 1-5. http://doi.org/10.1016/j.jclepro.2012.07.015

Uta Jttner, H. P. \& M. C. (2003). Supply chain risk management: outlining an agenda for future research. International Journal of Logistics Research and Applications: A Leading Journal of Supply Chain Management, 6, 197-210.

Vachon, S., \& Klassen, R. D. (2006). Extending Green Practices across the Supply Chain The impact of upstream and downstream integration. InternationalJournalofOperations\& ProductionManagement, 26 (7), 795-821.

Van Marrewijk, M. (2003). Concepts and definitions of CSR and corporate sustainability: Between agency and communion. Journal of business ethics,44(2-3), 95-105.

Varadarajan, P. R. (1992). Marketing's contribution to strategy: The view from a different looking glass. Journal of the Academy of Marketing Science, 20,335-343.

Veerakamolmal P., \& Gupta S. M. (2002). Acase-based reasoning approach for automating disassembly process planning. Journal of Intelligent Manufacturing, 13(1), 47-60.

Verdecho, M. J., Alfaro-Saiz, J. J., \& Rodriguez-Rodriguez, R. (2014). A performance measurement framework for monitoring supply chain sustainability. In Annals of Industrial Engineering 2012 (pp. 331-338). Springer London.

Walton, S. V., Handfield, R. B., \& Melnyk, S. A. (1998). The green supply chain: integrating suppliers into environmental management processes. Journal of Supply Chain Management, 34(2), 2.

Wagner, M., Schaltegger, S., \& Wehrmeyer, W. (2001). The relationship between the environmental and economic performance of firms. Greener Management International, (34), 94-111.

Wagner. (2005). How to reconcile environmental and economic performance to improve corporate sustainability. Journal of Environmental Management, 76, 105-118.

Wilkerson T. (2005). Best practices in implementing green supply chains. LMI Consulting. SupplyChain World-North America 2005 Conference \& Exposition, Disneyland, Anaheim, California, USA.

Winkler. (2011a). Closed-loop production systems A sustainable supply chain approach. CIRP Journal of Manufacturing Science and Technology, 4, 243-246.

Winkler, H. (2011b). Closed-loop production systems-A sustainable supply chain approach. CIRP Journal of Manufacturing Science and Technology, 4(3), 243-246. 
http://doi.org/10.1016/j.cirpj.2011.05.001

Winn, M. L., \& Angell, L. C. (2000). Towards a process model of corporate greening. Organization Studies, 21(6), 1119-1147.

Winter, S. G. (2003). Understanding dynamic capabilities. Strategic Management Journal Special Issue: Why Is There a Resource-Based View? Toward a Theory of Competitive Heterogeneity, 24, 991-995,.

Wong L. T., \& Fryxell G. E. (2004). Stakeholder influences on environmental management practices: A study of fleet operations in Honk Kong (SAR), China. Transportation Journal, 43(4), 22-35.

Wu, H. J., \& Dunn, S. C. (1995). Environmentally responsible logistics systems. International Journal of Physical Distribution \& Logistics Management, 25(2), 20-38.

Zailani, S., Amran, A., \& Jumadi, H. (2011). Green innovation adoption among logistics service providers in Malaysia: an exploratory study on the managers' perceptions. International Business Management, 5(3), 104-113.

Zhang, Y. (1999). Green QFD-II: A life cycle approach for environmentally conscious manufacturing by integrating LCA and LCC into QFD matrices. International Journal of Production Research, 37(5), 1075-1091. http://doi.org/10.1080/002075499191418

Zhu, Q. H., \& Sarkis, J. (2004). Relationships between operational practices and performance among early adopters of green supply chain management practices in Chinese manufacturing enterprises. Journal of Operations Management, 22, 265-289. http://doi.org/10.1016/j.jom.2004.01.005

Zhu, Q., Sarkis, J., \& Lai, K. H. (2008). Confirmation of a measurement model for green supply chain management practices implementation.International journal of production economics, $111(2)$, 261273.

Zhu, Q., \& Sarkis, J. (2006). An inter-sectoral comparison of green supply chain management in China: drivers and practices. Journal of cleaner production, 14(5), 472-486.

Zhu, Q., Sarkis, J., \& Lai, K. (2007). Initiatives and outcomes of green supply chain management implementation by Chinese manufacturers. Journal of Environmental Management, 85(1), 179-189. http://doi.org/10.1016/j.jenvman.2006.09.003

Zsidisin, G. A., \& Hendrick, T. E. (1998). Purchasing's involvement in environmental issues: a multicountry perspective. Industrial Management \& Data Systems, 98(7), 313-320.

Zsidisin, G. A., \& Siferd, S. P. (2001). Environmental purchasing: a framework for theory development. European Journal of Purchasing \& Supply Management, 7(1), 61-73. 